Article

\title{
Assessment of the Impact of Small Hydropower Plants on the Ecological Status Indicators of Water Bodies: A Case Study in Lithuania
}

\author{
Laima Česonienè ${ }^{1, *}$ (D), Midona Dapkiene ${ }^{2}$ and Petras Punys ${ }^{3}(\mathbb{D}$ \\ 1 Institute of Environment and Ecology, Faculty of Forest Science and Ecology, Vytautas Magnus University, \\ Agriculture Academy, Studentu str. 11, LT-53361 Akademija, Kaunas distr., Lithuania \\ 2 Institute of Hydraulic Engineering, Faculty of Water and Land Management, Vytautas Magnus University, \\ Agriculture Academy, Universiteto str. 10, LT-53361 Akademija, Kaunas distr., Lithuania; \\ midona.dapkiene@vdu.lt \\ 3 Institute of Water Resources Engineering, Faculty of Water and Land Management, Vytautas Magnus \\ University, Agriculture Academy, Universiteto str. 10, LT-53361 Akademija, Kaunas distr., Lithuania; \\ petras.punys@vdu.lt \\ * Correspondence: laima.cesoniene1@vdu.lt; Tel.: +370-37-752224
}

Citation: Česonienè, L.;

Dapkienè, M.; Punys, P. Assessment of the Impact of Small Hydropower Plants on the Ecological Status Indicators of Water Bodies: A Case Study in Lithuania. Water 2021, 13, 433. https://doi.org/10.3390/ w13040433

Academic Editor: Marco Franchini Received: 20 December 2020

Accepted: 2 February 2021

Published: 7 February 2021

Publisher's Note: MDPI stays neutral with regard to jurisdictional claims in published maps and institutional affiliations.

Copyright: (c) 2021 by the authors. Licensee MDPI, Basel, Switzerland. This article is an open access article distributed under the terms and conditions of the Creative Commons Attribution (CC BY) license (https:// creativecommons.org/licenses/by/ $4.0 /)$.

\begin{abstract}
Hydropower plants produce renewable and sustainable energy but affect the river's physico-chemical characteristics and change the abundance and composition of the aquatic organisms. The impact of large HPPs on the ecological conditions of surface water bodies have been extensively studied, but less attention has been paid to environmental impact studies of small hydropower plants (SHPs). The impact of hydropeaking on both the river flow regime and ecosystems has been well-studied for peaking mode plants, mainly medium to large-sized ones. However, for small hydroelectric power plants, and especially for those in lowland rivers, the available information on water quality, benthic macroinvertebrates communities and fish abundance, and biomass is not sufficient. Ten small hydropower plants were selected, and the ecological status of water bodies was assessed in different parts of Lithuania. The studies were performed at the riverbed upstream from the SHPs, where the hydrological regime has not changed, and downstream from the SHPs. It was found that the small hydropower plants do not affect the physico-chemical values of the water quality indicators. This study demonstrated that the total number of benthic macroinvertebrates taxa (TS) is influenced by the concentration of nitrogen and suspended solids, the water flow, the river area, and the current speed; the number of EPT (Ephemeroptera (mayflies), Plecoptera (stoneflies), and Trichoptera (caddisflies)) taxa is influenced by the concentration of nitrogen and suspended solids. The studied indicators do not have a significant impact on biomass. The SHPs affect the fish abundance and biomass. The Lithuanian fish index (LFI) is influenced by the average depth and area of the river. Some SHPs operating in lowland areas may yield somewhat significant hydrograph ramping but more detailed investigation is needed to support the significance of this impact on the biological indices.
\end{abstract}

Keywords: small hydropower plant (SHP); ecological status indicators; water quality

\section{Introduction}

In many parts of the world, much attention is paid to the development of hydropower as one of the cheapest traditional, clean, and renewable energy sources [1-4]. The construction capacity of large hydropower plants (HPPs) is currently limited, but the construction of small hydropower plants (SHPs) is considered a renewable and sustainable energy supply alternative [5,6] with a minimal impact on the environment [7-10]. The environmental impact of hydropower plants can be reduced by using modern technologies [11].

Disruption of the natural regime of a river affects the river's ecological conditions, hydrochemical characteristics, and changes in the abundance and composition of organisms 
in the water body [12-17]. Hydropower plants affect ecosystems in a variety of ways, including fluctuating water flows and levels, fragmented river continuities, river morphology and bedrock structural changes, changes in the physicochemical properties of water due to siltation in the upper basin upstream, and erosion in the lower basin downstream [18-23]. The nature of HPP operation varies depending on the demand for the energy produced, which also affects habitat diversity, abundance, biodiversity, and productivity [24-26].

The effects of large HPPs on fresh surface water biota have been extensively studied, but less attention has been paid to environmental impact studies of small hydropower plants [27]. The International Energy Agency (IEA) states that small hydropower plants $(<10 \mathrm{MW})$ have a relatively small and local impact on the environment. Researchers have analyzed how hydropower plants affect river ecosystems [28-30].

The results of studies of rivers with SHPs did not show differences in the taxonomic composition of living organisms, but did show changes in the density of individuals and the abundance of some species [31]. Some authors reported that small hydropower plants have only a small impact on river biota downstream [15,30-34]. Some studies have shown that the impacts of SHPs on river water quality and the structures of biological communities may be equivalent to those of large HPPs [5,35-37]. This past work also indicates that anthropogenic factors are increasingly affecting river flora and fauna [38]. Although SHPs are installed in small- and medium-sized rivers, because of disruptions to the natural flow regime, differences in runoff and sediment regimes occur before and after the dam is installed [39-41]. Fluctuations in flow velocity and pressure negatively affect the living conditions of aquatic organisms [42,43].

Studies have also shown the impact of hydroelectric reservoirs on macroinvertebrate communities [31,44,45]. Large hydropower plants cause significant changes in macroinvertebrate communities due to habitat destruction, flow regulation, and temperature regime changes: Sensitive species disappear, and species' entropy densities increase [46,47]. Moreover, the impact of small hydropower plants decreases to eligible ecological levels only a few kilometers downstream [15]. Focusing on low flow due to the water diversions caused by an SHP, Mueller et al. [48] indicated that the main effects on fish were reductions of their density and biomass in affected areas. However, the results of investigations of cumulative biophysical effects of small ( $<50 \mathrm{MW})$ and large hydropower plants in China's Nu River basin reveal that biophysical impacts of small hydropower may outweigh those of large hydropower, particularly with regard to habitat and hydrologic change. These results suggest that more detailed studies of SHPs impact assessment may be needed [29].

Although many studies have been conducted to assess the impact of hydropower plants on river ecosystems, the effects of river regulation on fish populations in general are difficult to identify due to the possible differences between species [49-51]. It is important to conduct long-term, large-scale studies to establish links between physical changes in a water body and biological responses in living organisms [52,53]. Changes in the natural flow and thermal regime can have a significant impact on the biology, ecology, community composition, diversity, productivity, and other aspects of fish, macroinvertebrates, and aquatic vegetation $[21,25,49,51,54-58]$.

Changes in flow rates due to SHPs can directly and indirectly affect fish living downstream. Increased flow rates during hydropeaking can directly increase energy expenditures due to increased activity [59] and indirectly affect fish nutrition by increasing invertebrate abundance and invertebrate drift [57,60-62]. Changes in flow rates associated with river regulation have also been shown to alter the overall availability of habitat abundance [63], depending on how hydropower plant use affects river morphometry. Changes in food availability, habitats, and fish behavior can, moreover, affect composition of fish communities and population health $[55,56]$. Changes in food access due to river regulation and/or hydropeaking are also important for fish growth; however, based on the invertebrate community composition, increases in invertebrate abundance are likely driven in part by inputs from the reservoir $[61,62]$. 
Any hydropower plant operating in Lithuania must comply with the Regulations for the Operation and Maintenance of Reservoirs, which impose reservoir rule curves [64]

Besides recommending hydraulic structure maintenance and other environmental requirements, these regulations balance the multipurpose use of the reservoir by meeting environmental and social obligations. In particular, these regulations focus on the downstream releases of environmental flow and the drawdown limitations in the reservoir. The latter also accounts for the spawning periods of the fish. For SHP generation, the water drawdown level in reservoirs is severely constrained at $+/-0.1 \mathrm{~m}$ from the normal water level (NWL). As practice shows, this range of water abstraction by SHP turbines provides the right environmental conditions for keeping the reservoir water level as constant as possible but is not considered in this study.

However, sub-daily flow regime modifications in the lower reaches of the stream can be observed under fast changes in the operations of hydro turbines (i.e., stopping or starting) $[65,66]$, causing rapid changes in the streamflow stage and discharge patterns, mostly at an hourly or finer timescale, with hydrograph ramping taking place downstream from a power plant. This process, which is mostly associated with large hydro plants, is called hydropeaking when turbines operate in the power peak demand mode. Even though SHPs do not generate peak electricity, flow hydrograph ramping is frequently observed in some plants [67]. In this paper, the "ramping rate" refers to the rate of change of the water stage (in meters per hour), and "hydropeaking" refers to the mode of operation of a facility where water is released following electricity demand. It should be noted that there are no legally prescribed restrictions on the operating modes of turbines in terms of flow releases downstream of the watercourse to limit ramping or hydropeaking rates. In some countries, hydropeaking thresholds are the usual environmental practice [68].

To estimate the amount of fish in Lithuanian rivers, fish surveys are performed every year at about 150 selected river sites. The results indicate that the number of fish in Lithuanian rivers is gradually increasing, their living conditions are improving, and the salmon and brown trout populations are growing [69]. However, Kesminas and Repecka [70] indicated that after the construction of the Kaunas Hydropower Plant $(\mathrm{H}=20 \mathrm{~m})$ on the largest river in the country, the Nemunas, the number of fish communities decreased from 33 to 24 . The main cause was the absence of a fish pass.

Lithuanian scientists also studied the impact of the large Kaunas hydropower plant (HPP) on fish in the lower reaches of the Nemunas River downstream. Frequently switching HPP turbines on and off has been found to be the main cause not only of intensive riverbed washing but also of a significant decrease in the number of fish [20,70].

In Lithuania, the impact of SHPs on the water quality and macroinvertebrates was likewise studied. It was found that due to the dam built in the Virvyte River, fewer macroinvertebrate species and a significantly lower total abundance are present in the river areas upstream and downstream from the dam compared to the control sites [71].

Vaikasas et al. [30] indicated that the impacts on the river water quality, nutrient regime, and biota in the sites influenced by small hydropower plants are only localized. It is argued that the larger basin area and intensive land use for agriculture in the river basin play a more important role than SHPs.

Other emerging issues related to the use of SHP reservoirs, such as the expansion of aquatic vegetation growth and siltation (the latter mainly due to the accumulation of organic compounds), were not addressed in this study. This study identified not only potential adverse impacts on aquatic ecosystems or flows but also discussed measures to improve the sustainability of SHPs.

The aim of this research is to evaluate the impact of small hydroelectric power plants on indicators of the ecological status of water bodies. 


\section{Materials and Methods}

\subsection{Study Area}

The ecological status of water bodies at risk was assessed in accordance with the Procedure for Assessing the Ecological Status of Surface Water Bodies [72].

The investigated SHPs are shown in Figure 1, and their key features are provided in Table 1. It should be noted that no SHP in this study has yet been equipped with a fish pass.

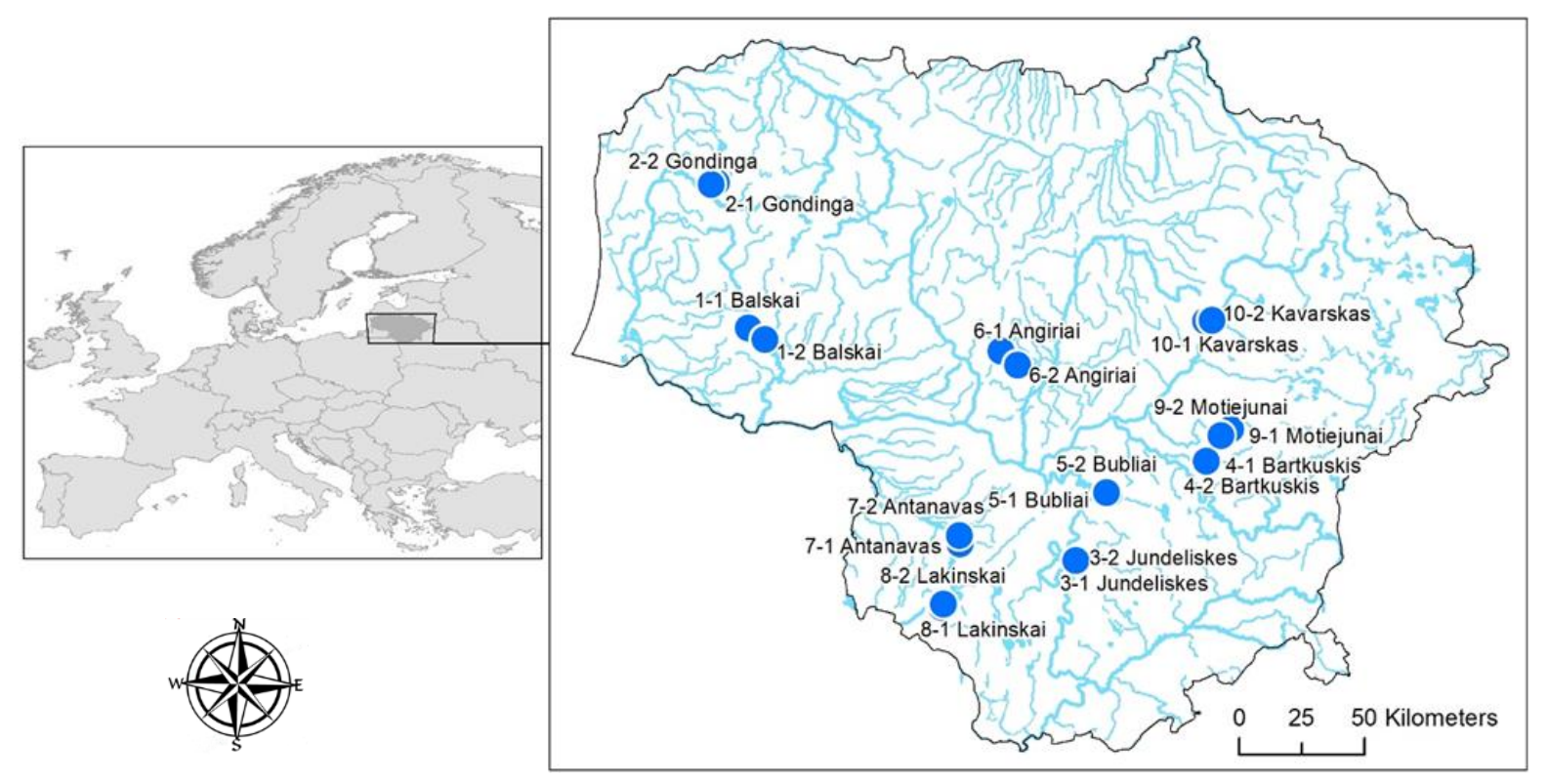

Figure 1. Research locations: 1-1 denotes upstream, 1-2 denotes downstream.

Lithuania is a low-lying country; therefore, the country's small hydropower plants are mostly low-head (up to $5 \mathrm{~m}$ ) or medium-head (between 5 and $15 \mathrm{~m}$ ). These plants operate on a run-of-the-river basis but involve relatively large water storage. Hydropower schemes consist of an impoundment with an earth-fill dam and integral or separated intake, with a powerhouse located at the dam toe. Traditional diversion schemes are quite rare. Due to the flat topography and low terrain gradient, their reservoir surface areas are also quite large, sometimes exceeding 1 or $2 \mathrm{~km}^{2}$ with corresponding water storage of a few millions $\mathrm{m}^{3}$ or more. Consequently, backwater stretches far behind the dam, sometimes up to $10 \mathrm{~km}$ or more.

Any impoundment in spatial and temporal terms affects river flow regimes and global river environments. To quantitatively represent the spatial and temporal intensity of the water mass (inflow or outflow) in the control area, a number of indicators were proposed, which can be described by the water retention time. The water retention time (reservoir filling period $D$ in hours) can be determined as follows:

$$
D=\frac{V_{u}}{Q_{0}},\left[\frac{\mathrm{m}^{3}}{\mathrm{~m}^{3} / \mathrm{h}}\right]
$$

where $V u$ is the useful capacity of the reservoir designated for power generation in $\mathrm{m}^{3}$, and $Q_{0}$ is the inflow into the reservoir (annual mean flow) in $\mathrm{m}^{3} / \mathrm{h}$. 
Table 1. SHP characteristics.

\begin{tabular}{|c|c|c|c|c|c|c|c|c|c|c|c|c|}
\hline \multirow{2}{*}{ No } & \multirow{2}{*}{$\begin{array}{l}\text { SHP and River } \\
\text { Name }\end{array}$} & \multicolumn{2}{|c|}{ Reservoir } & \multirow{2}{*}{$\begin{array}{l}\text { River Mean Annual } \\
\text { Flow, } Q_{0}, \mathrm{~m}^{3} / \mathrm{s}\end{array}$} & \multirow{2}{*}{ Head, m } & \multicolumn{3}{|c|}{ Turbines } & \multicolumn{2}{|c|}{$\begin{array}{l}\text { Turbine Max and Min Flow } \\
\text { vs. Mean Annual Flow }\end{array}$} & \multicolumn{2}{|c|}{$\begin{array}{c}\text { Turbine Min Flow vs. Low } \\
\text { Season and Environmental Flow }\end{array}$} \\
\hline & & $\begin{array}{l}\text { Surface } \\
\text { Area } \mathbf{k m}^{2}\end{array}$ & $\begin{array}{l}\text { Storage, } \\
\mathrm{Mm}^{3}\end{array}$ & & & $\begin{array}{c}\text { Installed } \\
\text { Capacity, MW }\end{array}$ & $\begin{array}{l}\text { Rated Flow, } \\
\mathrm{m}^{3} / \mathrm{s}\end{array}$ & $\begin{array}{l}\text { Type and } \\
\text { Number }\end{array}$ & $\mathrm{Q}_{\mathrm{MaxT}} / Q_{0}$ & $\mathrm{Q}_{\mathrm{MinT}} / Q_{0}$ & $\mathrm{Q}_{\mathrm{MinT}} / \mathrm{Q}_{\mathrm{minL}}$ & $\mathrm{Q}_{\mathrm{MinT}} / \mathrm{Q}_{\mathrm{e}}$ \\
\hline 1. & $\begin{array}{l}\text { Angiriai } \\
\text { Šušvė }\end{array}$ & 2.48 & 15.6 & 6.0 & 15.7 & $0.65+0.65$ & 10.2 & 2 Propeller & 1.70 & 0.80 & 7.27 & 14.12 \\
\hline 2. & $\begin{array}{c}\text { Antanavas } \\
\text { Šešupe }\end{array}$ & 1.08 & 1.49 & 9.59 & 5.3 & $0.2+0.2$ & 10.5 & 2 Propeller & 1.09 & 0.29 & 0.95 & 1.70 \\
\hline 3. & $\begin{array}{l}\text { Balskai } \\
\text { Jūra }\end{array}$ & 2.8 & 14.8 & 13.7 & 13 & $1.46+1.46+0.1$ & 25.1 & $\begin{array}{c}2+1 \text { Kaplan } \\
\text { (double } \\
\text { regulation) }\end{array}$ & 1.92 & 0.27 & 0.76 & $\sim 1$ \\
\hline 4. & $\begin{array}{l}\text { Bartkuškis } \\
\text { Muse }\end{array}$ & 0.61 & 1.51 & 1.74 & 8 & $0.05+0.1$ & 1.8 & $\begin{array}{l}2 \text { Kaplan } \\
\text { (single } \\
\text { regulation) }\end{array}$ & 1.04 & 0.28 & 1.20 & 4.00 \\
\hline 5. & $\begin{array}{l}\text { Bubliai } \\
\text { Obelis }\end{array}$ & 0.15 & 6.44 & 3.08 & 5.9 & 0.16 & 4.0 & Kaplan & 1.30 & 0.16 & 2.50 & 6.25 \\
\hline 6. & $\begin{array}{l}\text { Gondinga } \\
\text { Babrungas }\end{array}$ & 0.88 & 3.4 & 2.79 & 26,2 & 0.95 & 4.1 & Cross-flow & 1.47 & 0.24 & 1.19 & 2.34 \\
\hline 7. & $\begin{array}{l}\text { Jundeliškès } \\
\text { Verknè }\end{array}$ & 0.15 & 0.38 & 5.07 & 6 & $\begin{array}{l}0.12+0.12+ \\
0.12\end{array}$ & 5.1 & 3 Francis & 1.56 & 0.31 & 0.73 & 0.89 \\
\hline 9. & $\begin{array}{l}\text { Lakinskai } \\
\text { Šešupè }\end{array}$ & 0.06 & 0.06 & 5.43 & 3.4 & $0.08+0.08$ & 6.5 & 2 Kaplan & 1.20 & 0.43 & 0.49 & 2.06 \\
\hline 10. & $\begin{array}{c}\text { Motiejūnai } \\
\text { Širvinta }\end{array}$ & 0.87 & 1.96 & 2.81 & 5.2 & $0.11+0.11$ & 4.9 & 2 Francis & 1.70 & 0.39 & 2.82 & 4.23 \\
\hline
\end{tabular}


According to the water retention time in the reservoir or its filling period expressed in hours, hydropower plants can be divided into 3 groups: (a) run-of-river (RoR): $D \leq 2 \mathrm{~h}$ ( $\sim 0.1$ days); (b) pondage: $2 \mathrm{~h}<D<400 \mathrm{~h}(\sim 17$ days); and (c) storage: $D \geq 400 \mathrm{~h}$ [73]. The smaller the reservoir capacity and the higher the inflow into it are, the less regulated the natural flow will become [68]. It can be assumed that RoR developments with $D \leq 2 \mathrm{~h}$ have a relatively minimal impact on the river flow regime downstream from hydropower dams.

Based on this quantitative metric, only a few SHPs in this study can be viewed as RoR facilities $(D \leq 2 \mathrm{~h}$ ), with the remaining SHPs being of a pondage type (Figure 2).

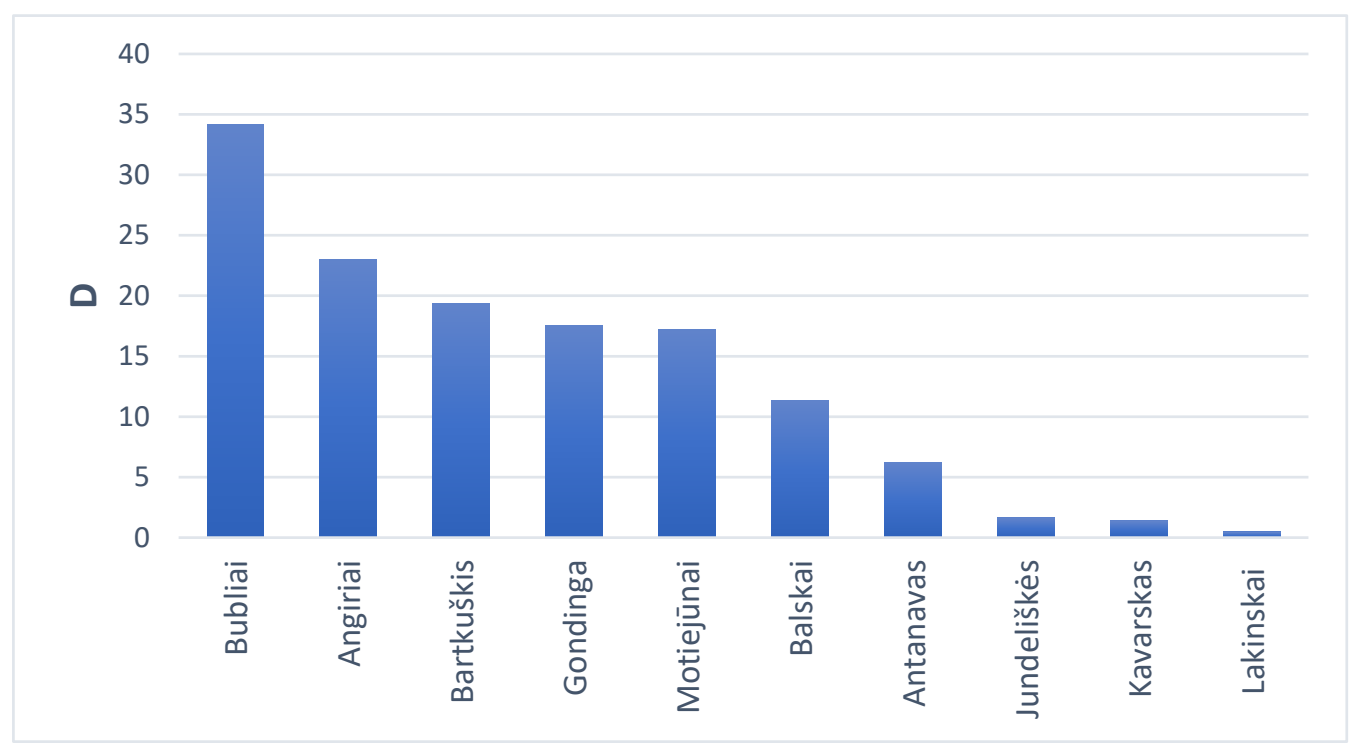

Figure 2. Water retention time (reservoir filling period $D$ in hours) in SHP reservoirs.

Notably the useful storage of SHP reservoirs designated for power generation is relatively small, corresponding to a water volume at $0.2 \mathrm{~m}$ of the drawdown height (or $+/-0.1 \mathrm{~m}$ from the normal head reservoir level).

\subsection{Climate Conditions}

The year of 2015 was dry in terms of total precipitation ( $499 \mathrm{~mm}$ or $79 \%$ of standard climatic norm (SCN). Compared to the multi-year average precipitation $(630 \mathrm{~mm})$, in 2015, the precipitation was $21 \%$ lower than the standard climatic norm (SCN). Water samples in 2015 were taken in April-May and July-August. Precipitation in April was 110\% of the multi-year precipitation rate, in May it was $80 \%$, and in July it was $91 \%$. August was particularly dry, with only $6.7 \mathrm{~mm}$ of rainfall $(9 \% \mathrm{SCN})$ during the whole month. September was similar to August. During the study period, the August air temperature was $3{ }^{\circ} \mathrm{C}$ higher than the average August temperature. These meteorological conditions have affected the river runoff and lake water levels. Many small streams have dried up altogether, and a hydrological drought has been declared. The year 2015 was generally characterized by a particularly warm winter season. The average monthly temperature in January-March was 3.3-4. ${ }^{\circ} \mathrm{C}$, and in December, the temperature was $5.4{ }^{\circ} \mathrm{C}$ higher than the norm. All of these deviations may have had an impact on the river water quality indicators.

\subsection{Sample Preparation (Collection)}

To determine the impact of SHPs on the status of water bodies, studies were performed on water bodies above the hydroelectric reservoir (in the riverbed upstream from the SHPs, where the hydrological regime has not changed due to the impact of the SHP reservoir) and downstream from the SHP reservoir.

Surveys of physico-chemical quality indicators and suspended solids were performed in January-December 2015, while benthic macroinvertebrates and fish studies were per- 
formed in August-September 2015. Ten small hydropower plants were selected in different parts of Lithuania. Figure 1 shows the areas where the studies were performed.

Studies on the physico-chemical quality element indicators were performed in the laboratory of Vytautas Magnus University. Water samples were taken according to EN ISO standards: LST EN ISO 5667-14:2016-water quality-Sampling-Part 14 [74]. The biochemical oxygen consumption $\left(\mathrm{BOD}_{7}\right)$ research was executed according to ISO 5815-2:2003 and the amount of suspended solids (SS) was determined by applying LST EN 872-2005. Total nitrogen $\left(\mathrm{N}_{\text {total }}\right)$ was tested according to the method of LST EN 13342-2002. The determination of nitrogen and bound nitrogen $\left(\mathrm{N}_{\text {total }}\right)$ following oxidation to nitrogen oxides used EN 12260:2003 [75]. Total phosphorus $\left(\mathrm{P}_{\text {total }}\right)$ analyses were performed according to LST EN ISO 6878:2004. The nitrate nitrogen $\left(\mathrm{NO}_{3}-\mathrm{N}\right)$ research was executed according to LAND 65:2005 [76]. The ammonium nitrogen $\left(\mathrm{NH}_{4}-\mathrm{N}\right)$ was determined according to LST ISO 7150-1:1998. The phosphate phosphorus $\left(\mathrm{PO}_{4}-\mathrm{P}\right)$ was determined according to the LST EN ISO 6878:2004 method.

Benthic macroinvertebrates research was carried out in accordance with the 2003 Regulations of the Minister of Environment of the Republic of Lithuania (December 24 by order no. 708, approved methodology LAND 57-2003, "Benthic macroinvertebrates research methodology in surface water bodies").

The fish research was carried out in accordance with the Minister of Environment of the Republic of Lithuania October 20 by order no. D1-501, approved by the Research Method of Fish Resources and the Minister of Environment of the Republic of Lithuania in 4 April 2007, by order no. D1-197. The Lithuanian environmental protection normative document, LAND 85-2007, "Methodology for calculating the Lithuanian fish index" (approved by D1-197) was used to evaluate the species composition, abundance, biomass, and age structures of the fish.

The research was carried out according to the established methodology using a certified electric fishing apparatus. The main parameters of the electric fishing device were as follows: current power in water up to $3000 \mathrm{~W}$, voltage up to $540 \mathrm{~V}$, frequency of electrical pulses up to $120 \mathrm{~Hz}$, pulse density 2-12 ms, and power supply from a $12 \mathrm{~V}$ battery. The fish were caught during maturation, and in the deeper sections of the river, the fishing was done by boat.

\subsection{Water Level Regime Downstream from the SHPs}

Many metrics were used to describe the hydropeaking or hydrograph ramping due to operations of water turbines $[68,77,78]$. The main metrics that were clearly observed in the lower reaches of the river (and that were considered in this study) were the range of water levels (the difference between the base-flow and peak-flow or their ratios), the rate at which the water levels rise and fall, and the distance after which the ramping almost disappears.

The downramping rate or slope of the hydrograph falling limb is considered to be more dangerous to aquatic ecosystems than the downramping of water [79]. Furthermore, downstream hydrograph ramping parameters were not directly related to the benthic macroinvertebrates or fish samples, or the indices of water quality. The study did not include measurements of the biotic effect of ramping

Fluctuations in water levels were recorded downstream from the dam in the turbine water release channel and further along the river (up to 3 to $9 \mathrm{~km}$ ) using data loggers. during the dry period (summer-autumn) at 9 SHPs (except for the Bubliai SHP, which discharged its flow to the lower buffer reservoir, thus avoiding stage variations). Besides the stages, the flow rates and turbine power were also monitored. In addition, gauged river stage data (at hourly intervals) were collected from SHP producers.

\subsection{Statistical Analyses}

Differences between the values of the physico-chemical and biological water quality indicators upstream and downstream the hydroelectric power plant were assessed by 
a Student's $t$ test. Used $t$-test independent by groups (upstream and downstream) The Statistica 9 software was used for this purpose, with the significance level set to $p<0.05$.

The impact of SHPs on the values of surface water quality indicators was assessed using the program SPSS 10.0. We assessed whether the impact of SHPs has a statistically significant impact on the water quality, determined which of them are most sensitive to SHP effects, and explored what the SHP effects are: the turbine power, flow rate $\mathrm{Q}_{0} \mathrm{~m}^{3} / \mathrm{s}$, average river depth, river area, stream velocity, reservoir flow, percentage of the river bottom occupied by vegetation, and the chemical water quality indicators $-\mathrm{BOD}_{7} ; \mathrm{N}_{\text {total }}$; $\mathrm{P}_{\text {total }}$; and concentration of suspended solids. The multiple linear regression model is

$$
\mathrm{Y}=\mathrm{a}+\mathrm{b}_{1} \mathrm{x}_{1}+\mathrm{b}_{2} \mathrm{x}_{2}+\ldots+\mathrm{b}_{\mathrm{k}} \mathrm{x}_{\mathrm{k}} \text {. }
$$

The multiple linear regression model contained the following variables: $Y$ is a dependent variable (benthic macroinvertebrates, number of EPT (Ephemeroptera (mayflies), Plecoptera (stoneflies), and Trichoptera (caddisflies)) taxa, Lithuanian fish Index LFI, total fish abundance, fish biomass); $a$ is constant; $b$ is an unstandardized coefficient; and $\mathrm{x}$ is an independent variable (and the chemical water quality indicators- $\mathrm{BOD}_{7} ; \mathrm{N}_{\text {total }} ; \mathrm{P}_{\text {total }} ;$ and concentration of suspended solids, the turbine power, flow rate $Q_{0} \mathrm{~m}^{3} / \mathrm{s}$, average river depth, river area, stream velocity, reservoir flow, percentage of the river bottom occupied by vegetation).

The Wilcoxon test, which is a non-parametric statistical hypothesis test, was used to compare two related samples to assess whether their population mean ranks differ [80,81]. A homogeneity test was used to compare two samples to verify whether or not they originated from the same population. Note that nonparametric tests do not involve precise parameters or assumptions about the underlying distribution and are most suitable for short data series [82,83]. This test was applied to reveal the homogeneity of the two samples consisting of the Danish Stream Fauna Index (DSFI), the Fauna Autochthonous index (FAI), and the Lithuanian fish index (LFI) values determined upstream and downstream from the SHPs.

\section{Results}

\subsection{Effect of SHP on the Values of the Physico-Chemical Quality Element Indicators in Water}

To assess the impact of small hydropower plants on water status, water samples were taken upstream and downstream from the SHPs. The physico-chemical and biological indicators of water quality were then assessed. The results are shown in Figure 3.

By evaluating the values of water indicators below and above the small hydropower plants, it was found that the values above the hydropower plants are higher than those below the hydropower plants, although Student's $t$ value, which shows the differences between the values, was found to be insignificant $(p>0.05)$. This shows that hydropower plants do not have a negative impact on the physico-chemical values of water quality indicators. Higher values of these indicators are generally considered to indicate poorer conditions, so the differences, although not significant, suggest conditions downstream of SHPs are better than upstream of the SHP.

\subsection{Effect of Water Level Fluctuations below SHP on Hydrobiological Indicators (DSFI, FAI, and LFI)}

The significance of the effect was determined according to the determined values of Lithuanian fish index (LFI), Danish Stream Fauna Index (DSFI), and Fauna Autochthonous index (FAI) upstream and downstream from the SHP. Lithuanian fish index-an indicator of the ecological status of a surface water body, which shows changes in the structure and composition of the Lithuanian ichthyofauna caused by human activities; the indicator for estimating the taxonomic composition and abundance of zoobenthos in water is the Danish Index of River Fauna (DSFI.). Fauna Autochthonous Index-an indicator that shows the naturalness of surface water body zoobenthos communities. The data are presented in Figures 4-7, which summarize all investigated SHPs. The representativeness of these data is outlined in Table 2. The data on the figures are described later in this section. 

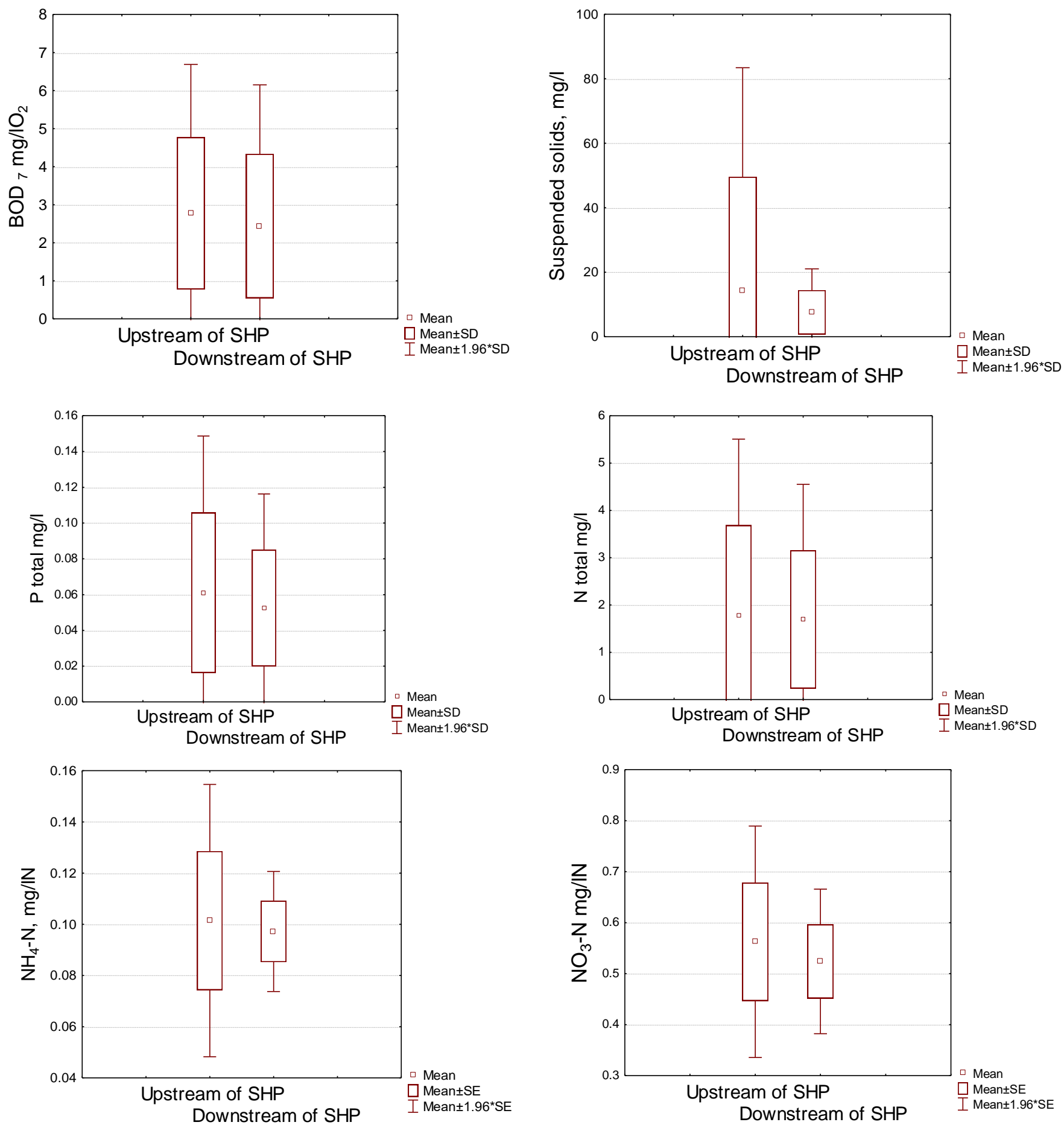

Figure 3. Water quality indicators $\left(\mathrm{P}_{\text {total }} ; \mathrm{N}_{\text {total }} ; \mathrm{NH}_{4}-\mathrm{N} ; \mathrm{NO}_{3}-\mathrm{N} ; \mathrm{BOD}_{7}\right.$; suspended solids). 


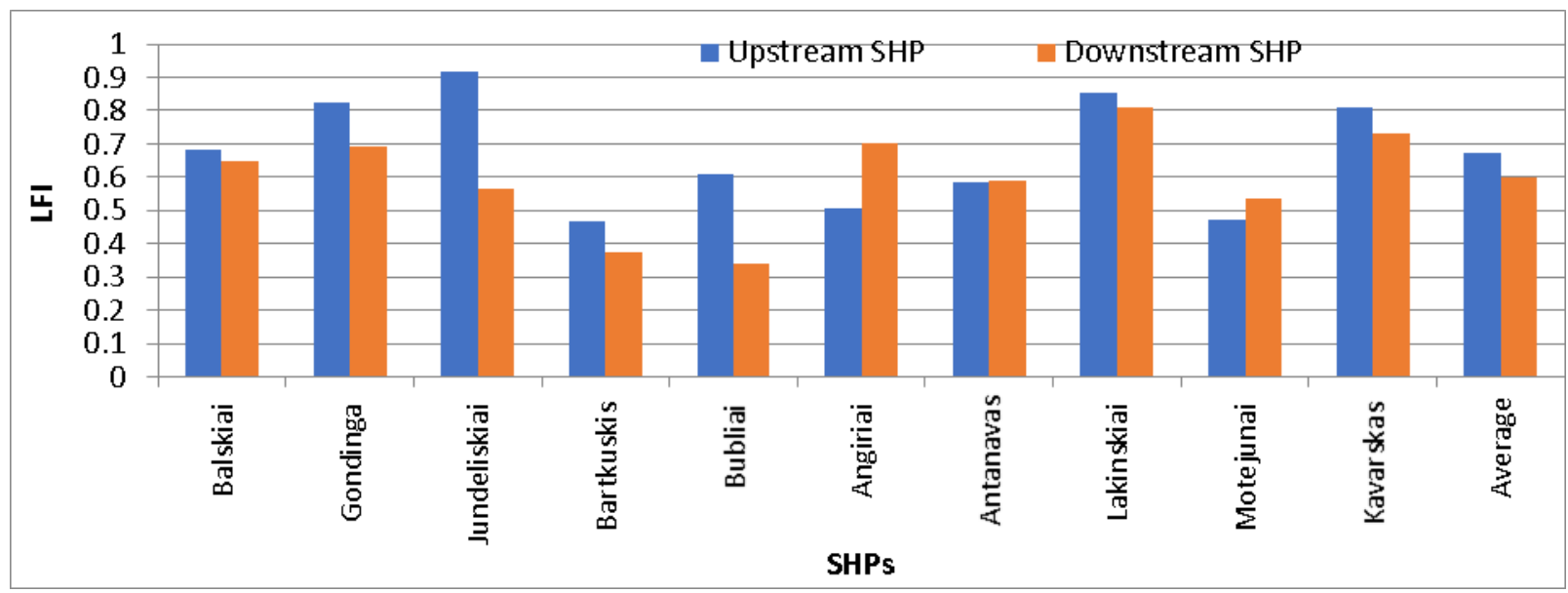

Figure 4. Lithuanian fish index (LFI) values upstream and downstream SHP dams.
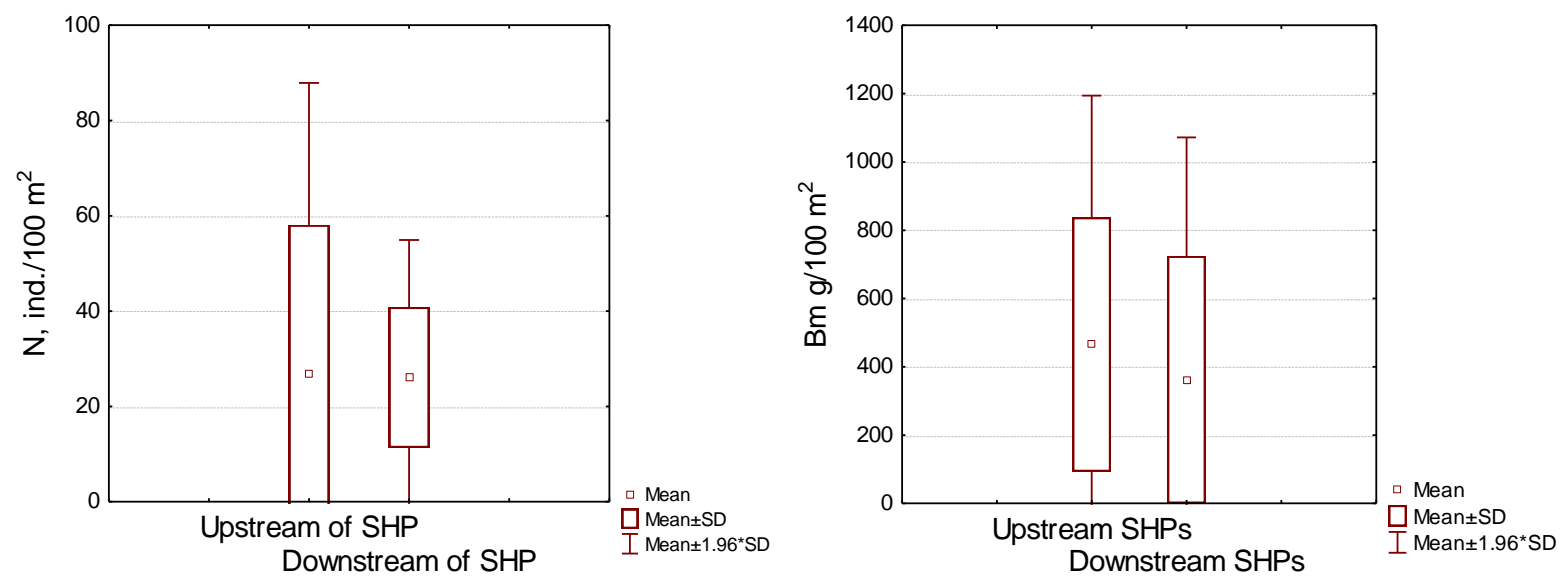

Figure 5. Fish abundance $\left(\mathrm{N}\right.$, ind. $\left./ 100 \mathrm{~m}^{2}\right)$ (individuals $\left./ 100 \mathrm{~m}^{2}\right)$ and biomass $\left(\mathrm{Bm}, \mathrm{g} / 100 \mathrm{~m}^{2}\right)$ upstream and downstream from the SHPs.

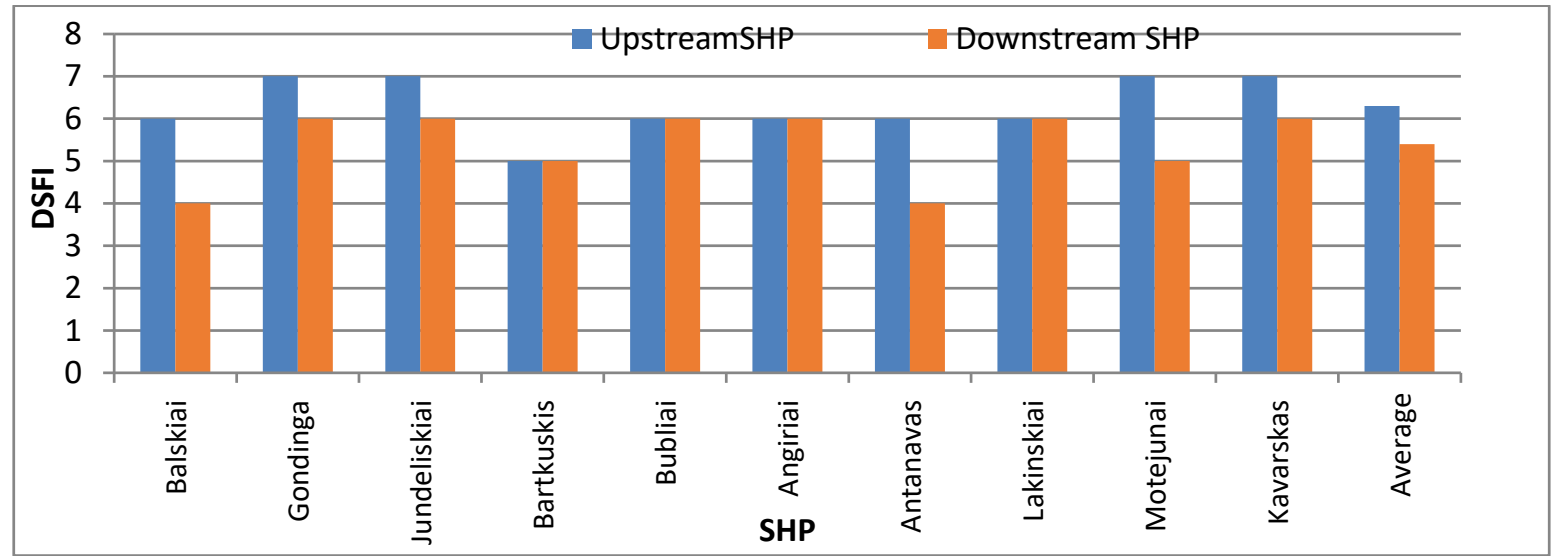

Figure 6. Danish Stream Fauna Index (DSFI) values upstream and downstream from the SHPs. 


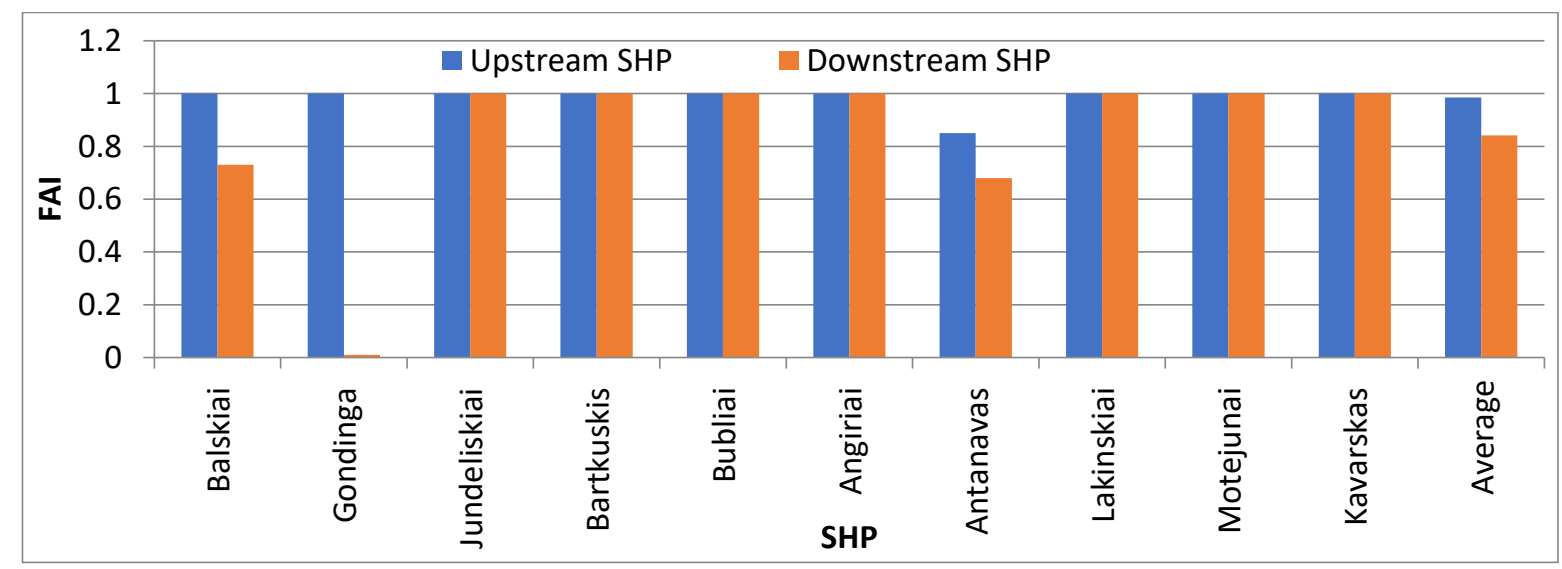

Figure 7. Fauna Autochthonous index (FAI) values upstream and downstream from the SHPs.

Table 2. The Wilcoxon homogeneity test for two samples.

\begin{tabular}{|c|c|c|c|c|c|c|}
\hline \multirow[b]{2}{*}{ Index } & \multicolumn{2}{|c|}{ Sample Mean } & \multirow[b]{2}{*}{ Calculated W } & \multirow[b]{2}{*}{$\begin{array}{c}\text { Critical } \\
W_{p}\end{array}$} & \multirow[b]{2}{*}{$\begin{array}{c}\text { Hypothesis } \\
\text { H0, H1 }\end{array}$} & \multirow[b]{2}{*}{ Conclusion } \\
\hline & $\begin{array}{l}\text { Upstream } \\
\text { Dam }\end{array}$ & $\begin{array}{c}\text { Downstream } \\
\text { Dam }\end{array}$ & & & & \\
\hline DSFI & 6.3 & 5.4 & 2.29 & 0.0220 & $\mathrm{H}_{5 \%} \mathrm{~W}>\mathrm{W}_{\mathrm{p}}$ & Rejected \\
\hline FAI & 0.985 & 0.941 & 0 & 1 & $\mathrm{H}_{5 \%} \mathrm{~W}<\mathrm{W}_{\mathrm{p}}$ & Not rejected \\
\hline LFI & 0.679 & 0.627 & 0.486 & 0.627 & $\mathrm{H}_{5 \%} \mathrm{~W}<\mathrm{W}_{\mathrm{p}}$ & Not rejected \\
\hline
\end{tabular}

Note: $\mathrm{H} 0$ and $\mathrm{H} 1$ denote that the averages of the two samples are equal or different.

LFI values can range from 0 to 1 with 0 being worst and 1 being best condition. In 7 out of 10 SHPs, the ecological status according to the LFI downstream from the SHP was found to be worse than that upstream (Balskai, Gondinga, Jundeliškès, Bartkuškis, Bubliai, Kavarskas and Lakinskai). Mean LFI values also were higher upstream than downstream of SHPs.

For the calculating the Lithuanian fish index (LFI) evaluates the species composition, abundance $(\mathrm{N})$, biomass $(\mathrm{Bm})$, age structure of fish. By calculating the differences between fish abundance $\left(\mathrm{N}\right.$, ind. $\left./ 100 \mathrm{~m}^{2}\right)$ and biomass $\left(\mathrm{Bm}, \mathrm{g} / 100 \mathrm{~m}^{2}\right)$ below hydroelectric power plants and above hydroelectric power plants, it was found that the biomass upstream from the SHP is significantly higher than that downstream. This difference is statistically significant $(p<0.05)$ for the Jundeliškès and Kavarskas SHPs. Fish abundance upstream from the SHP was found to be significantly higher than that downstream; this difference was found to be statistically significant $(p<0.05)$ for the Lakinskai SHP and Kavarskas SHP.

DSFI values can range from 0 to 1 , with 0 being worst and 1 being best condition. The results of the research showed that out of the 10 SHPs, seven (the Balskai, Gondinga, Jundeliškès, Motiejūnai, Kavarskas and Antanavas SHPs) featured DSFI values downstream from the SHPs that were worse than those upstream. However, the ecological status according to the DSFI downstream from the SHPs was only three points worse than that upstream. The mean DSFI values were also found to be worse downstream from the SHPs.

FAI values can range from 0 to 1 , with 0 being worst and 1 being best condition. The results of this research showed that in four out of 10 SHPs, the ecological status according to the FAI values downstream from the SHPs is worse than that upstream. The mean FAI values are also worse downstream from the SHPs.

Neither the FAI nor the LFI averages in the unaffected section of the river and downstream from the SHPs differed significantly. In contrast, the DSFI index shows a clear difference between the row averages. Notably, these results summarize all SHPs studied, rather than each SHP individually. 
A Wilcoxon test was used to quantify the statistical significance of the impact of SHP water level fluctuations in the lower reaches on aquatic ecosystems, as expressed by the biological indices (DSFI, FAI and LFI). Notably, these indices were determined upstream from the SHP reservoir, where water level fluctuations are natural, and downstream from the dam, where they are relatively intense under the operational regime of turbines.

Generally speaking, the pair value of any index resulting from measurements downstream and upstream from the SHP can characterize this impact. However, the significance of this impact (belonging (or not) to the same population) can be substantiated by a Wilcoxon test. Logically, lower values of these biological indicators were expected in the lower channel reaches of the SHPs compared to the upper reaches, where the impact of the backwater is no longer felt, but there are also other cases. In some lower sections of the SHPs, the LFI values are higher than those behind the respective dams (e.g., Angiriai, by 0.72 times; Motiejūnai, by 0.88 times). The sample size, however, was not large (10). The test results are presented in Table 2.

\subsection{Influence of Hydroelectric and Chemical Water Quality Indicators on Hydrobiological} Indicators (DSFI, FAI, and LFI)

The effect of hydroelectric and chemical water quality indicators on the total number of benthic macroinvertebrates taxa TS (Y) was calculated by a multiple regression analysis. The results are presented in Table 3.

Table 3. Influence of hydroelectric and chemical water quality indicators on the total number of benthic macroinvertebrates taxa (TS) downstream from the SHP.

\begin{tabular}{|c|c|c|c|c|c|}
\hline \multirow{2}{*}{ Environmental Factor } & \multicolumn{2}{|c|}{ Non-Standardized Coefficients } & \multirow{2}{*}{$\begin{array}{c}\text { Standardized Coefficient } \\
\text { Beta }\end{array}$} & \multirow{2}{*}{$\mathbf{t}$} & \multirow{2}{*}{$\begin{array}{c}\text { Significance Level } \\
p<0.05\end{array}$} \\
\hline & B & Standard Error & & & \\
\hline Constant & 69.339 (a) & 18.957 & & 3.658 & 0.008 \\
\hline $\mathrm{BOD}_{7}, \mathrm{mg} / \mathrm{L}\left(\mathrm{x}_{1}\right)$ & $-1.017\left(b_{1}\right)$ & 1.733 & -0.176 & -0.587 & 0.576 \\
\hline${ }^{*} \mathrm{~N}_{\text {total }}, \mathrm{mg} / \mathrm{L}\left(\mathrm{x}_{2}\right)$ & $-4.371\left(b_{2}\right)$ & 1.350 & -0.793 & -3.238 & 0.014 \\
\hline $\mathrm{P}_{\text {total }}, \mathrm{mg} / \mathrm{L}\left(\mathrm{x}_{3}\right)$ & $-75.669\left(b_{3}\right)$ & 76.652 & -0.335 & -0.987 & 0.356 \\
\hline $\begin{array}{c}\text { * Suspended solids, } \\
\mathrm{mg} / \mathrm{L}\left(\mathrm{x}_{4}\right)\end{array}$ & $0.677\left(\mathrm{~b}_{4}\right)$ & 0.203 & 1.164 & 3.339 & 0.012 \\
\hline Turbine power, kW $\left(x_{5}\right)$ & $0.001\left(b_{5}\right)$ & 0.004 & 0.069 & 0.323 & 0.756 \\
\hline${ }^{*} Q_{0} \mathrm{~m}^{3} / \mathrm{s}\left(\mathrm{x}_{6}\right)$ & $1.118\left(\mathrm{~b}_{6}\right)$ & 0.514 & 1.313 & 2.177 & 0.046 \\
\hline $\begin{array}{l}\text { The average depth of the } \\
\text { river, } \mathrm{m}\left(\mathrm{x}_{7}\right)\end{array}$ & $-10.261\left(b_{7}\right)$ & 6.405 & -0.337 & -1.602 & 0.153 \\
\hline $\begin{array}{l}\text { Vegetation, percentage } \\
\text { of riverbed cover }\left(\mathrm{x}_{8}\right)\end{array}$ & $-0.028\left(b_{8}\right)$ & 0.053 & -0.112 & -0.518 & 0.621 \\
\hline $\begin{array}{l}\text { Reservoir retention time, } \\
\qquad D\left(\mathrm{x}_{9}\right)\end{array}$ & $-0.146\left(b_{9}\right)$ & 0.264 & -0.212 & -0.555 & 0.596 \\
\hline${ }^{*}$ River area, $\mathrm{m}\left(\mathrm{x}_{10}\right)$ & $-1.295\left(b_{10}\right)$ & 0.501 & -1.708 & -2.587 & 0.036 \\
\hline${ }^{*}$ Flow rate, $\mathrm{m} / \mathrm{s}\left(\mathrm{x}_{11}\right)$ & $-18.427\left(b_{11}\right)$ & 7.775 & -0.632 & -2.370 & 0.050 \\
\hline
\end{tabular}

* Significance factor, $p<0.05$.

A multiple regression analysis of the influence of hydroelectric and chemical water quality indicators on the total number of benthic macroinvertebrates taxa (TS) showed that the TS value is influenced by nitrogen and suspended solid concentrations (a higher $\mathrm{N}_{\text {total }}$ concentration means a lower number of taxa; a higher concentration of suspended solids means a higher number of taxa), water flow $Q$ (a higher flow means a higher number of taxa), river area, and current velocity (a higher river width and current velocity means a lower number of taxa). 
The effect of hydroelectric and chemical water quality indicators on the number of EPT (Ephemeroptera (mayflies), Plecoptera (stoneflies), and Trichoptera (caddisflies)taxa was calculated by a multiple regression analysis. The results are presented in Table 4 .

Table 4. Influence of hydroelectric and chemical water quality indicators on the number of EPT ((Ephemeroptera (mayflies), Plecoptera (stoneflies), and Trichoptera (caddisflies)), taxa downstream from the SHP.

\begin{tabular}{|c|c|c|c|c|c|}
\hline \multirow{2}{*}{ Environmental Factor } & \multicolumn{2}{|c|}{ Non-Standardized Coefficients } & \multirow{2}{*}{$\begin{array}{c}\text { Standardized Coefficient } \\
\text { Beta }\end{array}$} & \multirow{2}{*}{$\mathbf{t}$} & \multirow{2}{*}{$\begin{array}{c}\text { Significance Level } \\
p<0.05\end{array}$} \\
\hline & B & Standard Error & & & \\
\hline Constant & 45.677 (a) & 11.605 & & 3.936 & 0.006 \\
\hline $\mathrm{BOD}_{7}, \mathrm{mg} / \mathrm{L}\left(\mathrm{x}_{1}\right)$ & $-1.620\left(b_{1}\right)$ & 1.061 & -0.396 & -1.527 & 0.171 \\
\hline${ }^{*} \mathrm{~N}_{\text {total }}, \mathrm{mg} / \mathrm{L}\left(\mathrm{x}_{2}\right)$ & $-2.968\left(b_{2}\right)$ & 0.826 & -0.761 & -3.591 & 0.009 \\
\hline $\mathrm{P}_{\text {total }}, \mathrm{mg} / \mathrm{L}\left(\mathrm{x}_{3}\right)$ & $-88.483\left(b_{3}\right)$ & 46.925 & -0.554 & -1.886 & 0.101 \\
\hline $\begin{array}{l}\text { * Suspended solids, } \\
\mathrm{mg} / \mathrm{L}\left(\mathrm{x}_{4}\right)\end{array}$ & $0.528\left(\mathrm{~b}_{4}\right)$ & 0.124 & 1.286 & 4.257 & 0.004 \\
\hline Turbine power, kW $\left(\mathrm{x}_{5}\right)$ & $0.001\left(b_{5}\right)$ & 0.002 & 0.117 & 0.629 & 0.549 \\
\hline$Q_{0} \mathrm{~m}^{3} / \mathrm{s}\left(\mathrm{x}_{6}\right)$ & $0.537\left(\mathrm{~b}_{6}\right)$ & 0.314 & 0.893 & 1.710 & 0.131 \\
\hline $\begin{array}{l}\text { The average depth of the } \\
\text { river, } \mathrm{m}\left(\mathrm{x}_{7}\right)\end{array}$ & $-3.903\left(b_{7}\right)$ & 14.714 & -0.082 & -0.265 & 0.798 \\
\hline $\begin{array}{l}* \text { Vegetation, percentage } \\
\text { of riverbed cover }\left(x_{8}\right)\end{array}$ & $-7.474\left(b_{8}\right)$ & 3.921 & -0.347 & -1.906 & 0.048 \\
\hline $\begin{array}{l}\text { Reservoir retention time, } \\
\qquad \mathrm{D}\left(\mathrm{x}_{9}\right)\end{array}$ & $-0.289\left(b_{9}\right)$ & 0.162 & -0.592 & -1.791 & 0.116 \\
\hline${ }^{*}$ River area, $\mathrm{m}\left(\mathrm{x}_{10}\right)$ & $-0.761\left(b_{10}\right)$ & 0.306 & -1.420 & -2.483 & 0.042 \\
\hline${ }^{*}$ Flow rate, $\mathrm{m} / \mathrm{s}\left(\mathrm{x}_{11}\right)$ & $-10.003\left(b_{11}\right)$ & 4.759 & -0.485 & -2.102 & 0.049 \\
\hline
\end{tabular}

* Significance factor, $p<0.05$.

The influence of hydroelectric and chemical water quality indicators on the number of EPT (Ephemeroptera (mayflies), Plecoptera (stoneflies), and Trichoptera (caddisflies)) taxa was also performed. The multiple regression analysis showed that the number of EPTs is influenced by higher nitrogen and suspended matter concentrations (the higher the concentration of suspended solids, the higher the number of EPTs), the percentage of vegetation cover on the riverbed (the higher the vegetation cover, the lower the number of EPTs), the river area, and the current velocity (the higher the width of the river, the lower the number of EPTs).

The impact of hydroelectric and chemical water quality indicators on the Lithuanian fish index LFI and fish abundance $(\mathrm{Y})$ was calculated by a multiple regression analysis. The results are presented in Tables 5 and 6. 
Table 5. Influence of small hydroelectric power plant and chemical water quality indicators on the Lithuanian fish index (LFI) downstream from the SHP.

\begin{tabular}{|c|c|c|c|c|c|}
\hline \multirow{2}{*}{ Environmental Factor } & \multicolumn{2}{|c|}{ Non-Standardized Coefficients } & \multirow{2}{*}{$\begin{array}{c}\text { Standardized Coefficient } \\
\text { Beta }\end{array}$} & \multirow{2}{*}{$\mathbf{t}$} & \multirow{2}{*}{$\begin{array}{c}\text { Significance Level } \\
p<0.05\end{array}$} \\
\hline & B & Standard Error & & & \\
\hline Constant & -0.117 & 0.382 & & -0.307 & 0.767 \\
\hline $\mathrm{BOD}_{7}, \mathrm{mg} / \mathrm{L}\left(\mathrm{x}_{1}\right)$ & 0.000 & 0.035 & -0.002 & -0.006 & 0.995 \\
\hline $\mathrm{N}_{\text {total }}, \mathrm{mg} / \mathrm{L}\left(\mathrm{x}_{2}\right)$ & 0.019 & 0.027 & 0.156 & 0.695 & 0.510 \\
\hline $\mathrm{P}_{\text {total }}, \mathrm{mg} / \mathrm{L}\left(\mathrm{x}_{3}\right)$ & -0.801 & 1.543 & -0.161 & -0.519 & 0.620 \\
\hline $\begin{array}{l}\text { Suspended solids, } \mathrm{mg} / \mathrm{L} \\
\left(\mathrm{x}_{4}\right)\end{array}$ & 0.002 & 0.004 & 0.159 & 0.499 & 0.633 \\
\hline Turbine power, kW ( $\left.\mathrm{x}_{5}\right)$ & $3.644 \times 10^{-5}$ & 0.000 & 0.100 & 0.511 & 0.625 \\
\hline$Q_{0} \mathrm{~m}^{3} / \mathrm{s}\left(\mathrm{x}_{6}\right)$ & 0.020 & 0.010 & 1.047 & 1.898 & 0.100 \\
\hline $\begin{array}{l}\text { * The average depth of } \\
\text { the river, } \mathrm{m}\left(\mathrm{x}_{7}\right)\end{array}$ & 1.538 & 0.484 & 1.040 & 3.180 & 0.015 \\
\hline $\begin{array}{l}\text { Vegetation, percentage } \\
\text { of riverbed cover }\left(x_{8}\right)\end{array}$ & -0.074 & 0.129 & -0.111 & -0.576 & 0.583 \\
\hline $\begin{array}{l}\text { Reservoir retention time, } \\
\qquad D\left(\mathrm{x}_{9}\right)\end{array}$ & -0.004 & 0.005 & -0.250 & -0.717 & 0.497 \\
\hline River area, m $\left(x_{10}\right)$ & -0.023 & 0.010 & -1.406 & -2.328 & 0.053 \\
\hline Flow rate, $\mathrm{m} / \mathrm{s}\left(\mathrm{x}_{11}\right)$ & -0.145 & 0.156 & -0.226 & -0.926 & 0.385 \\
\hline
\end{tabular}

* Significance factor, $p<0.05$.

Table 6. Influence of small hydroelectric power plants and chemical water quality indicators on total fish abundance downstream from the SHP.

\begin{tabular}{|c|c|c|c|c|c|}
\hline \multirow{2}{*}{ Environmental Factor } & \multicolumn{2}{|c|}{ Non-standardized Coefficients } & \multirow{2}{*}{$\begin{array}{c}\text { Standardized Coefficient } \\
\text { Beta }\end{array}$} & \multirow{2}{*}{$\mathbf{t}$} & \multirow{2}{*}{$\begin{array}{c}\text { Significance Level } \\
p<0.05\end{array}$} \\
\hline & B & Standard Error & & & \\
\hline Constant & 10.078 & 96.397 & & 0.105 & 0.920 \\
\hline $\mathrm{BOD}_{7}, \mathrm{mg} / \mathrm{L}\left(\mathrm{x}_{1}\right)$ & -2.488 & 8.813 & -0.137 & -0.282 & 0.786 \\
\hline $\mathrm{N}_{\text {total }}, \mathrm{mg} / \mathrm{L}\left(\mathrm{x}_{2}\right)$ & -1.210 & 6.865 & -0.070 & -0.176 & 0.865 \\
\hline $\mathrm{P}_{\text {total }}, \mathrm{mg} / \mathrm{L}\left(\mathrm{x}_{3}\right)$ & 37.373 & 389.786 & 0.053 & 0.096 & 0.926 \\
\hline $\begin{array}{l}\text { Suspended solids, } \mathrm{mg} / \mathrm{L} \\
\left(\mathrm{x}_{4}\right)\end{array}$ & -0.479 & 1.030 & -0.264 & -0.464 & 0.656 \\
\hline Turbine power, $\mathrm{kW}\left(\mathrm{x}_{5}\right)$ & -0.009 & 0.018 & -0.170 & -0.489 & 0.640 \\
\hline$Q_{0} \mathrm{~m}^{3} / \mathrm{s}\left(\mathrm{x}_{6}\right)$ & 1.089 & 2.611 & 0.409 & 0.417 & 0.689 \\
\hline $\begin{array}{l}\text { The average depth of the } \\
\text { river, } \mathrm{m}\left(\mathrm{x}_{7}\right)\end{array}$ & -41.854 & 122.226 & -0.199 & -0.342 & 0.742 \\
\hline $\begin{array}{l}\text { Vegetation, percentage } \\
\text { of riverbed cover }\left(x_{8}\right)\end{array}$ & -15.672 & 32.572 & -0.165 & -0.481 & 0.645 \\
\hline $\begin{array}{l}\text { Reservoir retention time, } \\
\qquad D\left(\mathrm{x}_{9}\right)\end{array}$ & 1.347 & 1.342 & 0.624 & 1.004 & 0.349 \\
\hline River area, $\mathrm{m}\left(\mathrm{x}_{10}\right)$ & 0.473 & 2.546 & 0.200 & 0.186 & 0.858 \\
\hline Flow rate, $\mathrm{m} / \mathrm{s}\left(\mathrm{x}_{11}\right)$ & 27.413 & 39.535 & 0.301 & 0.693 & 0.510 \\
\hline
\end{tabular}

A multiple regression analysis of the influence of hydroelectric and chemical water quality indicators on the Lithuanian fish index for the LFI showed that the value of the LFI is influenced by the average depth and area of the river (the higher the average depth of the river, the higher the LFI). 
The performed multiplier regression analysis of the impact of hydroelectric and chemical water quality indicators on the total fish abundance showed that the studied indicators do not have a significant impact on the total fish abundance.

The impact of hydroelectric and chemical water quality indicators on total fish biomass (was calculated by a multiple regression analysis. The results are presented in Table 7.

Table 7. Influence of small hydroelectric power plant and chemical water quality indicators on total fish biomass downstream from the SHP.

\begin{tabular}{|c|c|c|c|c|c|}
\hline \multirow{2}{*}{ Environmental Factor } & \multicolumn{2}{|c|}{ Non-Standardized Coefficients } & \multirow{2}{*}{$\begin{array}{c}\text { Standardized Coefficient } \\
\text { Beta }\end{array}$} & \multirow{2}{*}{$\mathbf{t}$} & \multirow{2}{*}{$\begin{array}{c}\text { Significance Level } \\
p<0.05\end{array}$} \\
\hline & B & Standard Error & & & \\
\hline Constant & 2928.758 & & 1487.314 & 1.969 & 0.090 \\
\hline $\mathrm{BOD}_{7}, \mathrm{mg} / \mathrm{L}\left(\mathrm{x}_{1}\right)$ & -218.726 & 135.974 & -0.775 & -1.609 & 0.152 \\
\hline $\mathrm{N}_{\text {total },} \mathrm{mg} / \mathrm{L}\left(\mathrm{x}_{2}\right)$ & 103.847 & 105.925 & 0.386 & 0.980 & 0.360 \\
\hline $\mathrm{P}_{\text {total }}, \mathrm{mg} / \mathrm{L}\left(\mathrm{x}_{3}\right)$ & -8930.346 & 6014.005 & -0.810 & -1.485 & 0.181 \\
\hline $\begin{array}{l}\text { Suspended solids, } \mathrm{mg} / \mathrm{L} \\
\left(\mathrm{x}_{4}\right)\end{array}$ & 20.331 & 15.899 & 0.718 & 1.279 & 0.242 \\
\hline Turbine power, kW $\left(x_{5}\right)$ & -0.290 & 0.278 & -0.359 & -1.044 & 0.331 \\
\hline $\mathrm{Q}_{0} \mathrm{~m}^{3} / \mathrm{s}\left(\mathrm{x}_{6}\right)$ & 11.790 & 40.291 & 0.284 & 0.293 & 0.778 \\
\hline $\begin{array}{l}\text { The average depth of the } \\
\text { river, } \mathrm{m}\left(\mathrm{x}_{7}\right)\end{array}$ & -1409.058 & 1885.829 & -0.430 & -0.747 & 0.479 \\
\hline $\begin{array}{l}\text { Vegetation, percentage } \\
\text { of riverbed cover }\left(\mathrm{x}_{8}\right)\end{array}$ & -597.768 & 502.558 & -0.402 & -1.189 & 0.273 \\
\hline $\begin{array}{l}\text { Reservoir retention time, } \\
\qquad D\left(\mathrm{x}_{9}\right)\end{array}$ & -30.065 & 20.703 & -0.892 & -1.452 & 0.190 \\
\hline River area, $\mathrm{m}\left(\mathrm{x}_{10}\right)$ & -8.418 & 39.282 & -0.228 & -0.214 & 0.836 \\
\hline Flow rate, $\mathrm{m} / \mathrm{s}\left(\mathrm{x}_{11}\right)$ & -215.289 & 609.978 & -0.151 & -0.353 & 0.735 \\
\hline
\end{tabular}

The performed multiple regression analysis of the impact of hydroelectric and chemical water quality indicators on the total fish biomass showed that the studied indicators do not have a significant impact on the total fish biomass.

\subsection{Hydrograph Ramping Downstream from SHP Dams}

Fluctuations in the water levels of several SHPs in the tailwater area are shown in Figures 8 and 9. It can be seen here that the Kavarskas SHP has a very smooth operating mode.

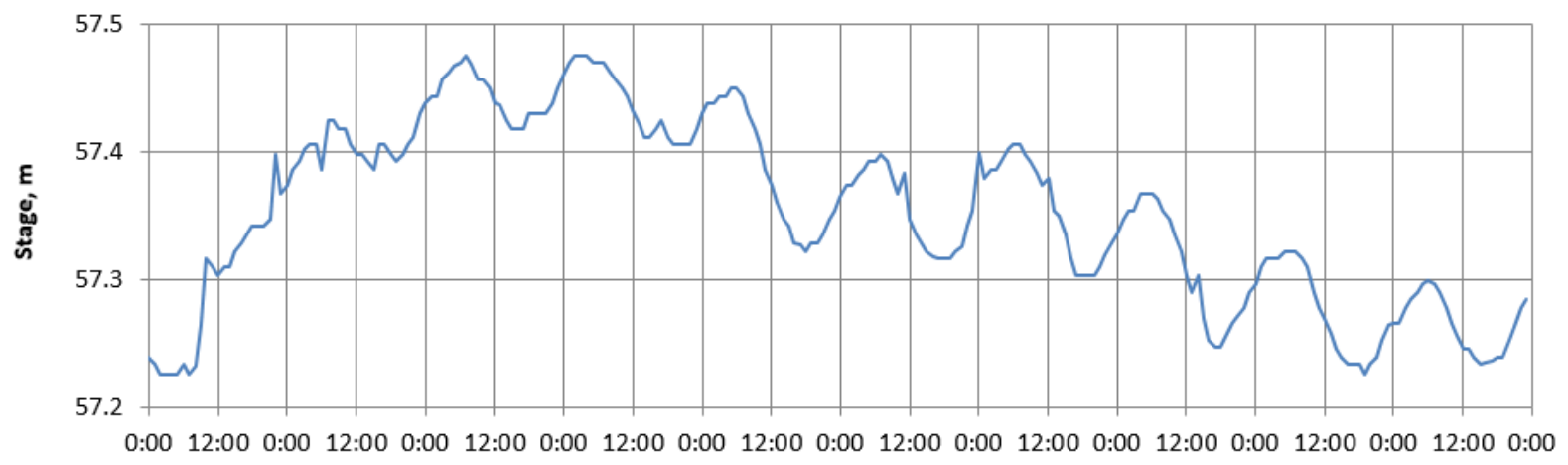

1 to 10 July 2014

Figure 8. Stage dynamics in the tailwater of the Kavarskas SHP during the operation of two turbines (457-570 kW). The range of the stage (wave height) is $<10 \mathrm{~cm}$. 


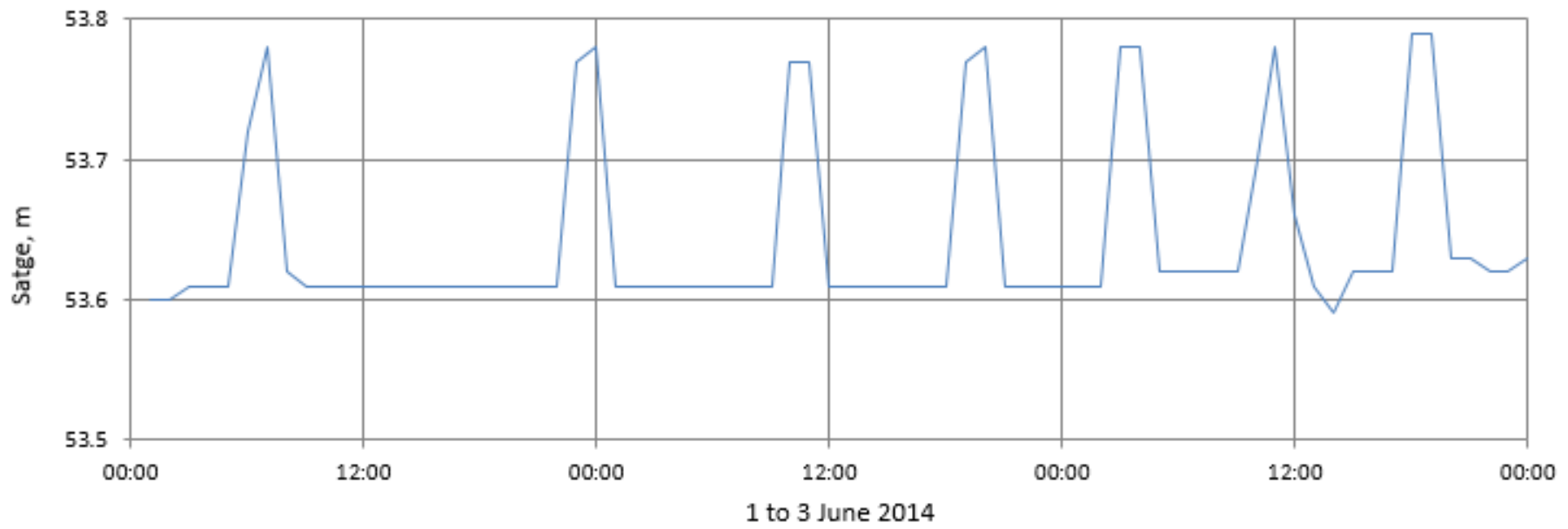

Figure 9. Stage dynamics in the tailwater of the Jundeliškès SHP during operation of one turbine (100 kW) and short-term start-up of the second turbine $(200 \mathrm{~kW})$.

This is due to the double-regulation Kaplan-type turbines, which offer very flexible flow control. The stage range (or wave height) of these turbines averages about $10 \mathrm{~cm}$, and the hydrograph upramping and downramping rate is about $1 \mathrm{~cm} / \mathrm{h}$. The values of these parameters are slightly higher for the Jundeliškès SHP, up to 17 and $8 \mathrm{~cm} / \mathrm{h}$, respectively (Figure 9).

These parameters are presented for all investigated SHPs (Figure 10).

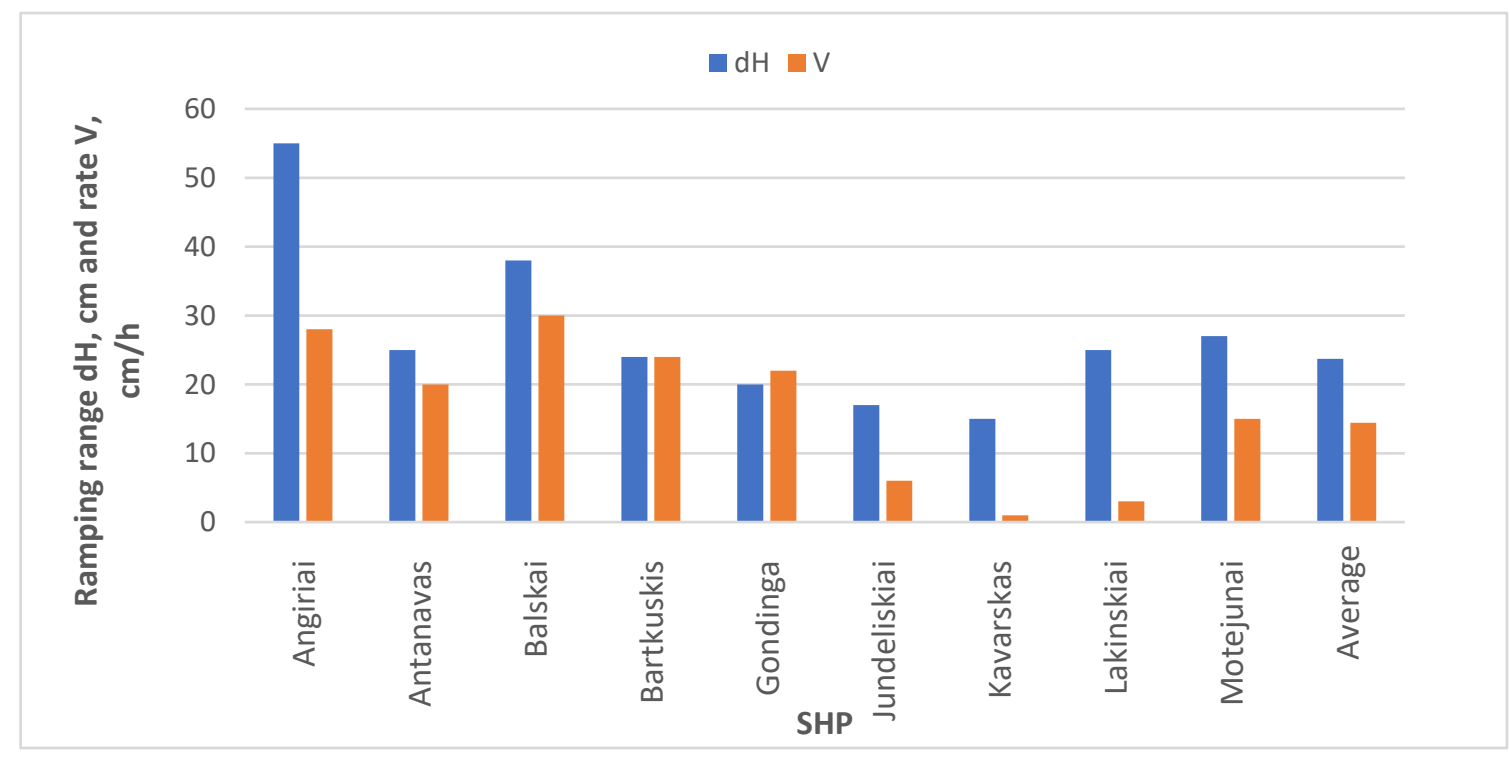

Figure 10. Ramping range (amplitude) $(\mathrm{dH})$ and ramping rate $(\mathrm{V})$ in the tailwater of SHP (maximum daily values).

The highest stage ranges were observed at the Angiriai SHP. This SHP is equipped with propeller turbines featuring low flow control capabilities. Their design flow is also high. Because these turbines are not adapted to the river flow regime, their flow rate is significantly higher than the river flow under normal conditions.

In addition to these parameters, it is very important to assess how far the surge generated by turbines extends along the length of the river or how fast it dampens. Of all the investigated SHPs, the Angiriai SHP ramping effect was felt furthest, at a distance of about $10 \mathrm{~km}$. This is very clearly shown by the gauging station located about $10 \mathrm{~km}$ downstream from the SHP (Figure 11). The average stage range decreased to $20 \mathrm{~cm}$, although it sometimes remained very significant. 


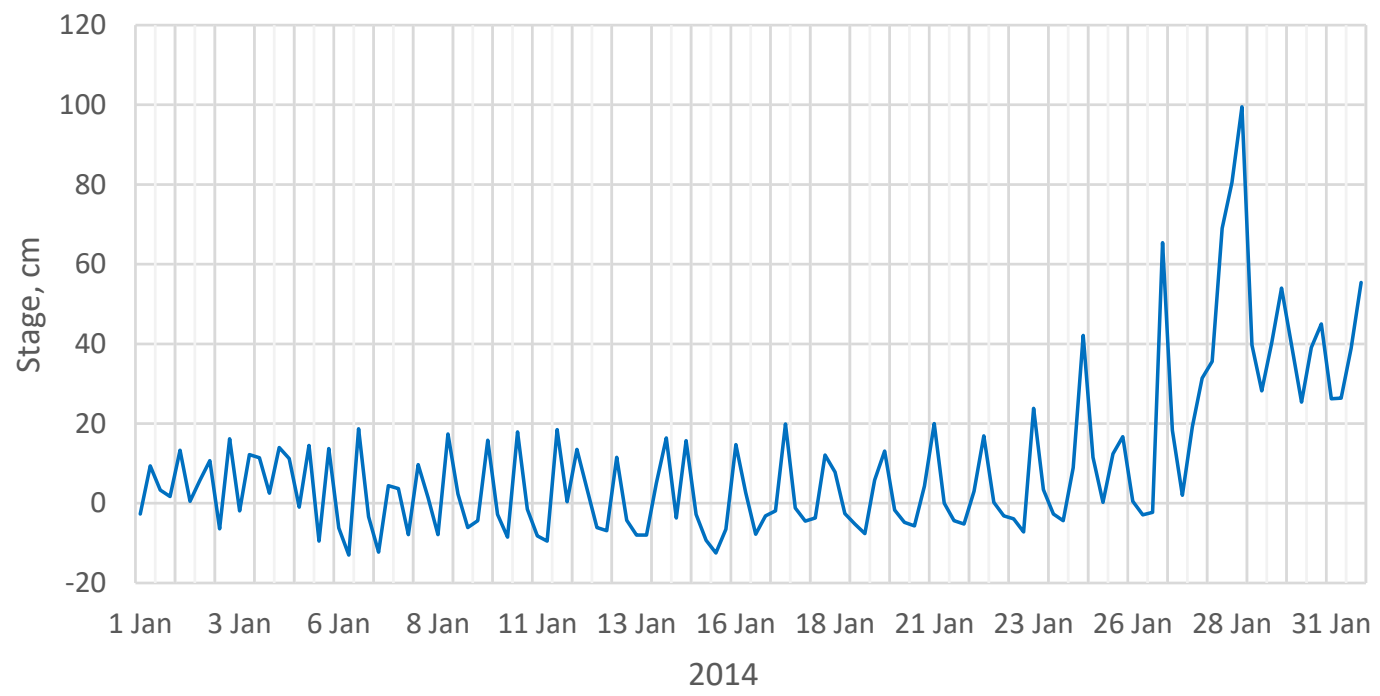

Figure 11. The Šušvè river stage hydrograph at the Josvainiai gauging station impacted by the operations of the Angiriai SHP (10.8 km upstream). Data source: Lithuanian hydrometeorological service.

\section{Discussion}

\subsection{Physico-Chemical Quality Element Indicators in Water}

Vaikasas et al. [30] examined the impact of 17 small hydropower plants built on five rivers in the country on river water quality and macroinvertebrates. The physicochemical parameters of the upstream and downstream tributaries and macroinvertebrate communities were also assessed. It was established that the construction of the dams $(\mathrm{H}<15 \mathrm{~m})$ changed the regimes of suspended solids and nutrients in the investigated rivers. However, dams of small hydropower plants (both low-head and medium-head) had a significant but local impact on the macroinvertebrate composition in these rivers.

Surveys were carried out on SHP dams of different heights in Lithuania in four rivers of the third to fourth order. The concentrations of suspended solids, total nitrogen, and total phosphorus were analyzed in each reservoir and river upstream of the reservoir and downstream of the SHP. The content of total nitrogen and total phosphorus in the reservoir bottom substrates was found to increase by several times compared to that in the upstream riverbed. In rivers below the plants, increased particle velocities removed smaller particles from the bed substrates due to increased flow velocity and turbulence, resulting in progress in the channeling of the river channel beds and a slight increase in suspended solids and total phosphorus [33].

The small hydropower plants change the regimes of suspended solids, particulate matter, and nutrients in Lithuanian rivers. Our studies show that small hydropower plants do not affect the physico-chemical values of water quality indicators. The higher the $\mathrm{N}_{\text {total }}$ concentration is, the lower the number of taxa will be due to the predominance of pollutionsensitive taxa; when the number of EPTs is lower, pollution-sensitive taxa predominate.

Because the suspended solids contain organic substances fed by benthic macroinvertebrates, the higher the concentration of suspended solids is, the higher the number of EPTs, the concentration of suspended solids, and the number of taxa will be. The higher the flow rate is, the higher the number of taxa will be, and the higher the river width and the lower the flow rate are, the lower the number of taxa will be. A higher current velocity removes (washes out) benthic macroinvertebrates individuals. Strong water currents also adversely affect the establishment of some hydrobionts in the soil. The higher the percentage of vegetation covering the riverbed is, the lower the number of EPTs will be. The number of EPT species depends on the type of soil. Most EPT species are found in stony sediments. Sediments are an important factor as a living substrate to which animals attach and through which caddisflies (Trichoptera) find materials to build dwellings. The higher the river 
width and the lower the current velocity are, the lower the number of EPTs will be. The higher the average depth of the river is, the higher the LFI will, and fish species that live at greater depths will predominate.

The present studies coincide with studies conducted in Spain. Álvarez et al. [12] investigated the impact of four small hydropower plants in north-western Spain on the water quality in four river sections where these SHPs are located. The results showed that the presence of hydropower plants did not have a significant effect on the physical and chemical properties of the water. The water quality of the Lérez River, which flows in north-western Spain, was studied after the construction of a small hydroelectric power plant. No statistically significant differences were observed between the upper and lower reaches of the river, which does not mean that the SHP did not have a significant impact on the water's biological quality during operations [3]. Studies have been carried out on the small hydropower plant of Vila Viçosa on the Ardena River (Portugal) to assess its impact on river water quality and the dynamics of benthic invertebrate communities. The impact on macroinvertebrate communities is smaller in front of the power plant, where the changes in flow rate throughout the year are minimal, resulting in a change in the structure of the community. Downstream of the power plant, where the flow rate varies greatly, the communities are impoverished, leading to the displacement of the substrate and organisms. The distribution of individuals is more strongly affected by the water temperature, dissolved oxygen concentration, flow rate, and riverbed substrate structure [35].

In China, 133 samples from seven rivers (Junan, Jiangxi, Fujian, and Hubei provinces) with 45 hydropower plants were analyzed to investigate the impacts of various types of small hydropower plants on macroinvertebrate communities. These dams affected benthic macroinvertebrates, whose taxon richness gradually increased from the reservoir to the lower reaches of the river and then to the natural reaches. Moreover, the biomass levels decreased. It was reported that the hydrological period was the main influencing factor and that the impact of the SHPs was not significant [84]. In this work, invertebrate studies in SHP reservoirs (low dams with clearly identified SHP types) were reviewed and systematized, concluding that the impact of small hydropower plant reservoirs and low dams is not clearly expressed for invertebrates, although the impact on more sensitive species was emphasized. This result may be related to the chemical status of the lower buffalo water. Moreover, smalls, in many cases, does not have a significant effect on the chemical status downstream from the dams, which is the same result as that in our research.

In our study, by calculating the differences between fish abundance $\left(\mathrm{N}\right.$, ind. $\left./ 100 \mathrm{~m}^{2}\right)$ and biomass $\left(\mathrm{Q}, \mathrm{g} / 100 \mathrm{~m}^{2}\right)$ below small hydroelectric power plants and above $\mathrm{SHP}$, it was found that the biomass upstream from the SHP is significantly higher than that downstream. A multiple regression analysis of the influence of hydroelectric and chemical water quality indicators on the Lithuanian fish index showed that the value of the LFI is influenced by the average depth and area of the river.

Fish populations and habitat characteristics were studied at the impact and control sites of 16 small hydropower plants on the River Ter in Catalonia, Spain. Higher fish abundance, higher average fish size, and better conditions at the control sites compared to SHPs were observed, but these results were different for individual fish species; some species had a higher relative abundance, while others were lower [27]. Mueller et al. [48] indicated that the main effects on fish were reductions of their density and biomass in affected areas. Freedman et al. [85] showed that the fish in the free-flowing section obtain nutrients mainly from bottom sources, while in the detained part, the fish are more dependent on pelagic substances. Hydropower plants can reduce the taxonomic diversity of fish, particularly through the depletion of lotus taxa, and shift the use of resources from the bottom to pelagic nutrients. See Mbaka and Mwaniki [86] for a review of 94 articles invertebrate studies.

The findings regarding the intensity of water level fluctuations in the lower tributary do not contradict the studies of Canadian ichthyologists [26,87]. These authors studied two rivers in detail, one with a natural flow and the other with an HPP operating in peak mode (for peak electricity generation) with large fluctuations in its flow/levels. Although 
significant differences in runoff and sediment regimes were found here, changes in biological parameters were not significant, including invertebrate abundance and diversity, fish biomass, fish conditions, and food/energy sources. However, significant differences were found between the taxa and fish diversity of some sensitive invertebrates.

Two rivers were studied in Northern Ontario (Canada) from 2002 to 2012: The Magpie River, where a 15 MW peaking hydropower plant was built, and the Batchawana River, which has a natural flow regime and control. Based on the data of this analysis, several general conclusions were drawn regarding the impact of river regulations on downstream fish populations related to the effects of river regulation on downstream fish populations: the impact of river regulation differs for different fish species. Moreover, hydrological and thermal indicators do not record the complexity of the reactions of fish species. [58].

\subsection{Hydrograph Ramping}

The impact of hydropeaking on both the river flow regime and ecosystems has been well studied for peaking mode plants, mainly for medium to large-sized ones $[77,88]$. However, for small hydropower plants, and especially for lowland rivers, this information is insufficient. On the other hand, hydropeaking is determined not only by the size of the power plant but also by many other surrounding factors that are site-specific. This assumption is a general rule not only for the analysis of the hydropeaking phenomenon but also for studying other processes.

The prevailing global conception is that SHPs operate in the run-of-river mode, as they have no large reservoirs, dams, or water storage $[89,90]$. However, the situation in lowland regions, as shown by the case of Lithuania, is entirely different. As shown in Table 1, the data for SHPs are associated with relatively high-water storage, but SHP capacities are low due to the relatively low operating head. Moreover, the RoR regime is best described by a quantitative parameter, where $D<2 \mathrm{~h}$ (formula 1), and the SHP operations associated with this value can ensure a more or less uniform regime in the lower part of the river. According to $D$, only a few of the SHPs studied are operating in the RoR mode, while others operate in the pondage mode (Figure 2). This phenomenon is clearly related to the significance of the main parameters of hydropeaking, e.g., the values of the Kavarskas SHP, Jundeliškès SHP, and Lakinskai SHP ramping parameters are lower. At the same time, the river flow regime is less disturbed downstream from the SHP dam compared to Angiriai, Bartkuškis, and other SHPs (Figure 10).

Besides the quantitative parameters $D$, the operating type of turbines, i.e., their number and rated capacity, have a significant influence on the change of the flow regime in the lower part of the river. In previous hydropeaking studies, these critical technical issues were not often emphasized. Water turbines that are used exclusively in lowland or flat areas are propeller-based, Kaplan single- and double-regulated, Francis, and Bank-MitchelOssberger types. It was proven that modern turbines can operate over a wide flow range while maintaining high efficiency. The propeller turbine, the simplest type of turbine, adapts the most poorly to a variable river flow regime. Therefore, such turbines should not be installed in rivers with unstable flow regimes [67]. However, increasing the number of these turbines and varying their individual capacities would ensure a more even river flow regime.

The Angiriai SHP operates two identical propeller turbines whose rated flow is $10.2 \mathrm{~m}^{3} / \mathrm{s}$, which corresponds to almost twice the average flow of the river $\left(\mathrm{Q}_{\mathrm{T}} \approx 2 \mathrm{Q}_{0}\right)$. This high-rated flow gives clear insight into the presence of significant hydrograph ramping. The range of the water level fluctuation is close to $60 \mathrm{~cm}$, and the rate of ramping is nearly $30 \mathrm{~cm} / \mathrm{h}$ (Figure 10). Turbines of this type operate relatively efficiently only at their rated flow; even small deviations from this flow will result in rapidly decreased efficiency. The situation in this SHP would be significantly improved if one turbine were to have a lower capacity. This modification would provide greater operational flexibility and, at the same time, a more even discharge of water flow into the lower reaches.

This is especially true in the case of the low-flow season. During this period, the minimum flow rate of the turbine is more than seven times higher than the low-season 
flow rate, and the duration of the low water period in Lithuania is at least 3 to 4 months. At this time point, because their operating time per day is relatively short, the turbines must be stopped to avoid short time flow pulses. The turbines, then, cannot work efficiently, which incurs significant losses of energy.

The exact opposite was observed for the Kavarskas SHP. This SHP contains two double-regulated Kaplan turbines with high flow rate control limits. The rated flow is lower than the average flow rate of the river (the ratio is 0.9 or $28 \mathrm{~m}^{3} / \mathrm{s}$ and $31.4 \mathrm{~m}^{3} / \mathrm{s}$, respectively). These turbines also operate efficiently during the low water season without causing ramping during this critical period.

As shown in Figure 10, in the investigated SHPs, the ramping rates ranged from $1 \mathrm{~cm} / \mathrm{h}$ to $30 \mathrm{~cm} / \mathrm{h}$. As the analysis of the literature shows, the ecologically acceptable values vary considerably based on local conditions, such as the type of fish and their developmental stages. Ramping rates above $30 \mathrm{~cm} / \mathrm{h}$ were associated with a poor ecological status in terms of the Fish index of Austria [40]. Ramping rates below $15 \mathrm{~cm} / \mathrm{h}$ increased the probability of a better ecological status.

The dewatering velocity rate thresholds $(\mathrm{cm} / \mathrm{h})$, which have the same meaning as the downramping rate when assessing the impact of hydropeaking, were considered for Norwegian rivers [90]. The highest impact was above $20 \mathrm{~cm} / \mathrm{h}$, and the smallest was below $5 \mathrm{~cm} / \mathrm{h}$.

Analysis of the historical flood records in free-flowing small-sized rivers (before damming) in Lithuania showed that the rate of the rising and falling limbs of the flood hydrograph is approximately 9 and $5 \mathrm{~cm} / \mathrm{h}$, respectively. Another critical issue must be mentioned here: the number of natural floods that occurs is low compared to the artificial flooding caused almost daily by turbine operations exclusively in moderate river channels.

A review of the hydropeaking thresholds values prescribed for small- and mediumsized rivers in Europe showed that base-flow to peak-flow threshold ratios of 1:1.5 to 1:3 are ecologically acceptable [68]. This condition is mostly valid for all investigated SHPs except two SHPs.

A longitudinal assessment of hydropeaking impacts at various scales was also considered to improve the process understanding and design of mitigation measures [91]. It was concluded that in the first $5 \mathrm{~km}$ downstream of the turbine outlet, a significant decrease in vertical ramping velocity occurs. However, in the lowland rivers, due to the low slopes of the riverbeds, the ramping effects occur far away from the outlets of the SHP turbines. Despite the apparent hydraulic resistance (aquatic vegetation and variety of channel geometry), the flatting of the water wave shape caused by turbines in the riverbed through its length is not significant. For example, the value of the Angiriai SHP, which is upstream the Josvainiai gauging station and more than $10 \mathrm{~km}$ away, is still high-on average, $20 \mathrm{~cm}$, with a maximum value of $60 \mathrm{~cm}$-and the value of the ramping rate is $2-6 \mathrm{~cm} / \mathrm{h}$ (Figure 11). The Jundeliškès SHP wave stretches up to $5 \mathrm{~km}$ or more. At this distance, the wave's height decreases by at least one third compared to the starting point at the power plant. In large-sized lowland rivers, the hydropeaking impact can be felt a long distance away (up to $40 \mathrm{~km}$ ) [92]. A variety of mitigation measures have been proposed, which can be globally grouped into direct and indirect measures [68,93-95]. Direct measures include operational and structural measures. Indirect measures address river morphological aspects through channel restructuring for habitat improvement.

As the results of this study show, only a few SHPs are subject to ramping mitigation measures. Only one Angiriai SHP is subject to a structural measure. This process could involve replacement of the propeller turbine with a turbine featuring more adjustable flow regulation capabilities or the construction of a compensation basin near the tailwater area. For the remaining SHPs, operational measures can be applied, consisting of a smooth start and a halt of the turbines to avoid sudden surges. These measures are based on a prolonged increase or decrease in the power of the turbines that must be started/stopped alongside the flow rate change. The minimum duration of the stepwise turbine start-up and shut-down process is set to half an hour. This procedure does not require high upfront costs. 


\section{Conclusions}

1. Evaluating the values of water indicators upstream and downstream from small hydropower plants, was found that the SHPs do not affect the physico-chemical values of the water quality indicators.

2. Evaluating the Lithuanian fish index (LFI) values upstream and downstream from small hydropower plants, was found that the SHPs affect the fish abundance $\left(\mathrm{N}\right.$, ind. $\left./ 100 \mathrm{~m}^{2}\right)$ and biomass $\left(\mathrm{Q}, \mathrm{g} / 100 \mathrm{~m}^{2}\right)$. A multiple regression analysis of the influence of hydroelectric and chemical water quality indicators on the Lithuanian fish index showed that the value of the LFI is influenced by the average depth and area of the river.

3. The performed multiple regression analysis of the influence of hydrological and power and chemical water quality indicators on the values of biological water quality indicators showed that the total number of benthic macroinvertebrates taxa TS is influenced by the concentration of nitrogen and suspended solids, water flow, river area, and current speed. The number of EPT (Ephemeroptera (mayflies), Plecoptera (stoneflies), and Trichoptera (caddisflies)) taxa is instead influenced by the concentration of nitrogen and suspended solids. The studied indicators do not have a significant impact on biomass.

4. Some SHP operations in lowland areas may result in significant flow hydrograph ramping. However, the ramping does not correlate to a significant impact on the biological indices.

Author Contributions: L.Č. designed the study and performed the experiments; L.Č., P.P. and M.D. performed the experiments, analyzed the data, and wrote the manuscript. All authors have read and agreed to the published version of the manuscript.

Funding: This research was partially funding by the LIFE Nexus project (LIFE17 ENV/ES/000252) entitled "Boosting the sustainability of the urban water cycle: energy harvest in water industry using micro-hydropower technology". This research was partially supported by the "Research Council of Lithuania" (Project BioRes No. S-LJB-20-3).

Data Availability Statement: Data available in a publicly accessible repository.

Conflicts of Interest: The authors declare no conflict of interest.

\section{References}

1. Yuksel, I. Hydroelectric Power in Developing Countries. Energy Sources Part B Econ. Plan. Policy 2009, 4, 377-386. [CrossRef]

2. Kaunda, C.S.; Kimambo, C.Z.; Nielsen, T.K. Hydropower in the Context of Sustainable Energy Supply: A Review of Technologies and Challenges. ISRN Renew. Energy 2012, 2012, 1-15. [CrossRef]

3. Valero, E. Characterization of the Water Quality Status on a Stretch of River Lérez around a Small Hydroelectric Power Station. Water 2012, 4, 815-834. [CrossRef]

4. Jager, H.; Efroymson, R.A.; Opperman, J.J.; Kelly, M.R. Spatial Design Principles for Sustainable Hydropower Development in River Basins. Renew. Sustain. Energy Rev. 2015, 45, 808-816. [CrossRef]

5. Premalatha, M.; Abbasi, T.; Abbasi, S.A. A critical view on the eco-friendliness of small hydroelectric installations. Sci. Total Environ. 2014, 481, 638-643. [CrossRef] [PubMed]

6. Spänhof, B. Current status and future prospects of hydropower in Saxony (Germany) compared to trends in Germany, the European Union and the World. Renew. Sust. Energy Rev. 2014, 30, 518-525. [CrossRef]

7. Aggidis, G.A.; Luchinskaya, E.; Rothschild, R.; Howard, D.C. The costs of small-scale hydro power production: Impact on the development of existing potential. J. Renew. Energy 2010, 35, 2632-2638. [CrossRef]

8. Juknys, R. Renewable energy development opportunities for sustainable development, Research papers, Sustainable Development Strategy and Practice. SDSSP 2010, 1, 4-10. (In Lithuanian)

9. Kosnik, L. The potential for small scale hydropower development in the US. Energy Policy 2010, 38, 5512-5519. [CrossRef]

10. Santos, J.M.; Silva, A.T.; Katopodis, C.; Pinheiro, P.J.; Pinheiro, A.N.; Bochechas, J.; Ferreira, M.T. Ecohydraulics of pool-type fishways: Getting past the barriers. Ecol. Eng. 2012, 48, 38-50. [CrossRef]

11. Govorushko, M.S.; Rupert, C.E. Hydropower: Types, Development Strategies and Environmental Impacts; Nova Science Publishers, Inc.: New York, NY, USA, 2014.

12. Álvarez, X.; Valero, E.; Torre-Rodríguez, N.; Acuña-Alonso, C. Influence of Small Hydroelectric Power Stations on River Water Quality. Water 2020, 12, 312. [CrossRef] 
13. Winterwerp, J.C.; Kesteren, W.G.M. Introduction to the Physic of Cohesive Sediment Dynamics in the Marine Environment; Elsevier Science: Amsterdam, The Netherlands, 2004; Volume 56, p. 466.

14. Greathouse, E.A.; Pringle, C.M.; McDowell, W.H.; Holmquist, J.G. Indirect upstream effects of dams: Consequences of migratory consumer extirpation in Puerto Rico. Ecol. Appl. 2006, 16, 339-352. [CrossRef] [PubMed]

15. Ambers, R.K.R. Effects of a small, century-old dam on a second order stream in Virginia Piedmont. Southeast. Geogr. 2007, 47, 181-201. [CrossRef]

16. Hu, W.; Wang, G.; Deng, W.; Li, S. The influence of dams on ecohydrological conditions in the Huaihe River basin, China. Ecol. Eng. 2008, 33, 233-241. [CrossRef]

17. Soulsby, R.L.; Manning, A.J.; Whitehouse, R.J.S.; Spearman, J.R. Development of a generic physically-based formula for the settling flux of natural estuarine cohesive sediment: Final Report-summary. In HR Wallingford Company Research Project DDY0409; HR Wallingford: London, UK, 2010.

18. Sear, D.A.; Carling, P.A.; Greig, S.M. Fine sediment accumulation in spawning gravels and the effects on interstitial flow. In Proceedings of the 5th Symposium on Ecohydraulics. Aquatic Habitats: Analysis \& Restoration, Madrid, Spain, 12-17 September 2004; pp. 808-812.

19. Lamsodis, R.; Vaikasas, S. The potential to retain nitrogen in beaver ponds and delta floodplains of the River Nemunas. Archiv fur Hydrobiologie Suppl. Large Rivers 2005, 15, 225-241. [CrossRef]

20. Zdankus, N.; Vaikasas, S.; Sabas, G. Impact of a hydropower plant on the downstream reach of a river. J. Environ. Eng. Landsc. Manag. 2008, 16, 128-134. [CrossRef]

21. Malik, A.U.; Richardson, J.S. Riparian vegetation change in upstream reaches of three temperate rivers dammed for hydroelectric generation in British Columbia, Canada. Ecol. Eng. 2009, 35, 810-819. [CrossRef]

22. Vaikasas, S. Mathematical modelling of sediment dynamics and their deposition in Lithuanian rivers and their deltas (case studies). J. Environ. Eng. Land. Manag. 2010, 18, 207-216. [CrossRef]

23. Young, P.S.; Cech, J.J., Jr.; Thompson, L.C. Hydropower-related pulsed-flow impacts on stream fishes: A brief review, conceptual model, knowledge gaps, and research needs. Rev. Fish Biol. Fish. 2011, 21, 713-731. [CrossRef]

24. Clarke, K.D.; Pratt, T.C.; Randall, R.G.; Scruton, D.A.; Smokorowski, K.E. Validation of the flow management pathway: Effects of altered flow on fish habitat and fishes downstream from a hydropower dam. In Canadian Technical Report of Fisheries and Aquatic Sciences No.2784; Her Majesty the Queen in Right of Canada: Nanaimo, BC, Canada, 2008.

25. Sabater, S. Alterations of the global water cycle and their effects on river structure, function and services. Freshw. Rev. 2008, 1, 75-88. [CrossRef]

26. Smokorowski, K.E.; Metcalfe, R.A.; Finucan, S.D.; Jones, N.; Marty, J.; Power, M. Ecosystemlevel assessment of environmentally based flow restrictions for maintaining ecosystem integrity: Acomparison of a modified peaking vs. unaltered river. Ecohydrology 2011, 4, 791-806. [CrossRef]

27. Benejam, L.; Saura-Mas, S.; Bardina, M.; Sola, C.; Munne, A.; Garcia-Berthou, E. Ecological impacts of small hydropower plants on headwater stream fish: From individual to community effects. Ecol. Freshw. Fish. 2016, 25, 295-306. [CrossRef]

28. Kantoush, S.A.; Sumi, T.; Murasaki, M. Evaluation of sediment by pass efficiency by flow field and sediment concentration monitoring techniques. Ann. J. Hydraul. Eng. JSCE 2011, 55, 169-174. [CrossRef]

29. Kibler, K.M.; Tullos, D.D. Cumulative biophysical effects of small and large hydropower development, Nu River, China. Water Resour. Res. 2013, 49, 3104-3118. [CrossRef]

30. Vaikasas, S.; Bastiene, N.; Pliuraite, V. Impact of small hydropower plants on physicochemical and biotic environments in flatland riverbeds of Lithuania. J. Water Sec. 2015, 1. [CrossRef]

31. Principe, R. Ecological effects of small dams on benthic macroinvertebrate communities of mountain streams (Co'rdoba, Argentina). Ann. Limnol. Int. J. Limnol. 2010, 46, 77-91. [CrossRef]

32. Sharma, C.M.; Sharma, S.; Borgstrom, R.; Bryceson, I. Impact of a small dam on macroinvertebrates: A case study in the Tinau River, Nepal. Aquat. Ecosyst. Health Manag. 2005, 8, 267-275. [CrossRef]

33. Vaikasas, S.; Lamsodis, R. Sediment and nutrient retention in reservoirs of small hydropower plants. In Proceedings of the 8th International Conference on Environmental Engineering, Technika, Vilnius, Lithuania, 19-20 May 2011; pp. 684-691.

34. Vaikasas, S.; Palaima, K.; Sabas, G. Hydraulic criteria and estimation of the hydropower plant (HPP) operation impact on the river environment. In Proceedings of the 8th International Conference on Environmental Engineering, Technika, Vilnius, Lithuania, 19-20 May 2011; pp. 692-697.

35. Jesus, T.; Formigo, N.; Santos, P.; Tavares, G.R. Impact evaluation of the Vila Viçosa small hydroelectric power plant (Portugal) on the water quality and on the dynamics of the benthic macroinvertebrate communities of the Ardena river. Limnetica 2004, 23, 241-256.

36. Mantel, S.K.; Hughes, D.A.; Muller, N.W.J. Ecological impacts of small dams on South African rivers. Part 1: Drivers of change: Water quantity and quality. Water S A 2010, 36, 351-360.

37. Mantel, S.K.; Muller, N.W.J.; Hughes, D.A. Ecological impact of small dams on South African rivers. Part. 2: Biotic responseabundance and composition of macroinvertebrate communities. Water SA 2010, 36, 361-370.

38. Baskaya, S.; Baskaya, E.; Sari, A. The principal negative environmental impacts of small hydropower plants in Turkey. Afr. J. Agric. Res. 2011, 6, 3284-3290. [CrossRef]

39. Santos, J.; Ferreira, M.; Pinheiro, A.; Bochechas, J. Effects of Small Hydropower Plants on Fish Assemblages in Medium-Sized Streams in Central and Northern Portugal. Aquat. Conserv. Mar. Freshw. Ecosyst. 2006, 16, 373-388. [CrossRef] 
40. Schmutz, S.; Melcher, A.; Jungwirth, M.; Schinegger, R.; Unfer, G.; Wiesner, C.; Zeiringer, B. Hydro peaking in Austria and its effects on aquatic organisms. In Proceedings of the Abstract Book of 8th International Symposium on Ecohydraulics, Seoul, Korea, 12-16 September 2010.

41. Rolls, R.J.; Leigh, C.; Sheldon, F. Mechanistic effects of low-flow hydrology on riverine ecosystems: Ecological principles and consequences of alteration. Freshw. Sci. 2012, 31, 1163-1186. [CrossRef]

42. Dolgopolova, E.N. River flow regulation impact upon habitat in nature streams. In Proceedings of the 5th International Symposium on Ecohydraulics. Aquatic Habitats: Analysis \& Restoration, Madrid, Spain, 12-17 September 2004; pp. 771-776.

43. Vaideliene, A.; Michailov, N. Dam influence on the river self-purification. In Proceedings of the 7th International Conference Environmental Engineering, 22-23 May 2008; Vilnius Gediminas Technical University: Lithuania, Vilnius, 2008 ; pp. $247-250$.

44. Katano, I.; Negishi, J.; Minagawa, T.; Doi, H.; Kawaguchi, Y.; Kayaba, Y. Longitudinal macroinvertebrate organization over contrasting discontinuities: Effects of a dam and tributary. J. North. Am. Benthol. Soc. 2009, 28, 331-351. [CrossRef]

45. Tszydel, M.; Grzybkowska, M.; Kruk, A. Influence of dam removal on trichoptera assemblages in the lowland Drzewiczka River, Poland. Hydrobiologia 2009, 630, 75-89. [CrossRef]

46. Grubbs, S.A.; Taylor, J.M. The influence of flow impoundment and river regulation on the distribution of riverine macroinvertebrates at Mammath cave National Park, Kentucky, USA. Hydrobiologia 2004, 520, 19-28. [CrossRef]

47. Doyle, M.W.; Stanley, E.H.; Strayer, D.I.; Jacobson, R.B.; Schmidt, J.C. Effective discharge analysis of ecological processes in streams. Water Resour. Res. 2005, 41. [CrossRef]

48. Mueller, M.; Pander, J.; Geist, J. The effects of weirs on structural stream habitat and biological communities. J. Appl. Ecol. 2011, 48, 1450-1461. [CrossRef]

49. Korman, J.; Campana, S.E. Effects of hydropeaking on nearshore habitat use and growth of age-0 rainbow trout in a large regulated river. Trans. Am. Fish. Soc. 2009, 138, 76-87. [CrossRef]

50. Poff, N.L.; Zimmerman, J.K.H. Ecological response to altered flow regimes: A literature review to inform the science and management of environmental flows. Freshw. Biol. 2020, 55, 194-205. [CrossRef]

51. Finch, C.; Pine, W.E., III; Limburg, K.E. Do hydropeaking flows alter juvenile fish growth rates? A test with juvenile Humpback Chub in the Colorado River. River Res. Appl. 2015, 31, 156-164. [CrossRef]

52. Mims, M.C.; Olden, J.D. Fish assemblages respond to altered flow regimes via ecological filtering of life history strategies. Freshw. Biol. 2013, 58, 50-62. [CrossRef]

53. Olden, J.D.; Konrad, C.P.; Melis, T.S.; Kennard, M.J.; Freeman, M.C.; Mims, M.C.; Bray, E.N.; Gido, K.B.; Hemphill, N.P.; Lytle, D.A.; et al. Are large-scale flow experiments informing the science and management of freshwater ecosystems? Front. Ecol. Environ. 2014, 12, 176-185. [CrossRef]

54. Lessard, J.L.; Hayes, D.B. Effects of elevated water temperature on fish and macroinvertebrate communities below small dams. River Res. Appl. 2003, 19, 721-732. [CrossRef]

55. Alexandre, C.M.; Quintella, B.R.; Ferreira, A.F.; Romao, F.A.; Almeida, P.R. Swimming performance and ecomorphology of the Iberian barbel Luciobarbus bocagei (Steindachner, 1864) on permanent and temporary rivers. Ecol. Freshw. Fish. 2014, 23, 244-258. [CrossRef]

56. Bond, M.J.; Jones, N.E. Spatial distribution of fishes in hydropeaking tributaries of Lake Superior. River Res. Appl. 2015, 31, 120-133. [CrossRef]

57. Bond, M.J.; Jones, N.E.; Haxton, T.J. Growth and Life History Patterns of a Small-bodied Stream Fish, Cottus cognatus, in Hydropeaking and Natural Rivers of Northern Ontario. River Res. Appl. 2016, 32, 721-733. [CrossRef]

58. Kelly, B. Effects of Hydroelectric Dam Operation on Downstream Fish. Populations A Thesis for the Degree of Doctor of Philosophy in Biology; Brianne Kelly: Waterloo, ON, Canada, 2016; p. 139.

59. Murchie, K.J.; Smokorowski, K.E. Relative activity of brook trout and walleyes in response to flow in a regulated river. North Amer. J. Fish. Manag. 2004, 24, 1050-1057. [CrossRef]

60. Lagarrigue, T.; Céréghino, R.; Lim, P.; Reyes-Marchant, P.; Chappaz, R.; Lavandier, P.; Belaud, A. Diel and seasonal variations in brown trout (Salmo trutta) feeding patterns and relationship with invertebrate drift under natural and hydropeaking conditions in a mountain stream. Aquat. Living Res. 2002, 15, 129-137. [CrossRef]

61. Patterson, R.J.; Smokorowski, K.E. Assessing the benefit of flow constraints on the drifting invertebrate community of a regulated river. River Res. Appl. 2011, 27, 99-112. [CrossRef]

62. Jones, N.E. Spatial patterns of benthic invertebrates in regulated and natural rivers. River Res. Appl. 2013, 29, 343-351. [CrossRef]

63. Bunn, S.E.; Arthington, A.H. Basic principles and ecological consequences of altered flow regimes for aquatic biodiversity. Environ. Manag. 2002, 30, 492-507. [CrossRef]

64. Ministry of Environment of the Republic of Lithuania. Regulations of Operation and Maintenance of Reservoirs.1997 (In Lithuanian)/Lietuvos Respublikos Aplinkos ministerija. Tvenkinių Naudojimo ir Priežiūros Tipinès Taisyklès (LAND 2-95). Available online: https:/ / e-seimas.lrs.lt/portal/legalAct/lt/TAD/TAIS.41898/asr (accessed on 3 February 2021).

65. Gostner, W.; Lucarelli, C.; Theiner, D.; Kager, A.; Premstaller, G.; Schleiss, A. A holistic approach to reduce negative impacts of hydropeaking. In Dams and Reservoirs under Changing Challenges; Taylor and Francis Group: London, UK, $2011 ;$ pp. 857-865.

66. Bejarano, M.D.; Jansson, R.; Nilsson, C. The effects of hydropeaking on riverine plants: A review. Biol. Rev. 2018, 93, 658-673. [CrossRef] [PubMed]

67. Punys, P.; Dumbrauskas, A.; Kasiulis, E.; Vyčienè, G.; Šilinis, L. Flow regime Changes: From Impounding a Temperate Lowland River to Small Hydropower Operations. Energies 2015, 8, 7478-7501. [CrossRef] 
68. Moreira, M.; Hayes, D.S.; Boavida, I.; Schletterer, M.; Schmutz, S.; Pinheiro, A. Ecologically-based criteria for hydropeaking mitigation: A review. Sci. Total Environ. 2019, 657, 1508-1522. [CrossRef] [PubMed]

69. Jatautas, J. An environmental assessment on hydropower development in Lithuania Environmental Economics. Environ. Econ. 2016, 7, 24-33. [CrossRef]

70. Kesminas, V.; Repecka, R. Human impact on fish assemblages in the Nemunas river, Lithuania. Large Rivers 2003, 15, 275-287. [CrossRef]

71. Vaikasas, S.; Palaima, K.; Pliūraite, V. Influence of hydropower dams on the state of macroinvertebrates assemblages in the Virvyte River, Lithuania. J. Environ. Eng. Landsc. Manag. 2013, 21, 305-315. [CrossRef]

72. Approval of the Description of the Procedure for Assessing the Ecological Status of Surface Water Bodies. Order of the Minister of the Environment of the Republic of Lithuania: 12 April 2007 No. D1-210. 2017 (In Lithuanian). Lietuvos Respublikos Aplinkos ministro Isakymas dèl Paviršiniu Vandens Telkinių Būklès Nustatymo Metodikos Patvirtinimo 2007m. Balandžio $12 \mathrm{~d}$. Nr. D1-210. Available online: https:/ / www.e-tar.lt/portal/lt/legalAct/TAR.881D6E973D28 (accessed on 11 April 2019).

73. Unipede-Eurelectric. Statistical Terminology Employed in the Electricity Supply Industry; Unipede-Eurelectic: Brussels, Belgium, 1991.

74. LST EN ISO 5667-14:2016 Vandens Kokybè. Mèginiu Ėmimas. In 14 dalis. Gamtinio Vandens Mèginiu Ėmimo ir Tvarkymo Kokybès Užtikrinimo bei Kokybès Kontrolès Nurodymai (ISO 5667-14:2014) Water Quality—Sampling_Part 14: Guidance on Quality Assurance and Quality Control of Environmental Water Sampling and Handling (ISO 5667-14:2014) EN ISO 5667-14:2016.CEN-CENELEC; Management Centre: Briussels, Belgium, 2016.

75. LST EN 12260:2004 Vandens Kokybè. Azoto Nustatymas. In Sujungtojo Azoto (Nb) Nustatymas Oksiduojant ji j Azoto Oksida Water Quality-Determination of Nitrogen-Determination of Bound Nitrogen (TN), Following Oxidation to Nitrogen Oxides EN 12260:2003; Management Centre: Briussels, Belgium, 2004.

76. LST EN ISO 6878:2004 Vandens Kokybe. Fosforo Nustatymas. In Spektrometrinis Metodas, Vartojant Amonio Molibdata (ISO 6878:2004) Water Quality_Determination of Phosphorus-Ammonium Molybdate Spectrometric Method (ISO 6878:2004) EN ISO 6878:2004; Management Centre: Briussels, Belgium, 2016.

77. Meile, T.; Boillat, J.-L.; Schleiss, A. Hydropeaking indicators for characterization of the Upper-Rhone River in Switzerland. Aquat. Sci. 2011, 73, 171-182. [CrossRef]

78. Sauterleute, J.F.; Charmasson, J.A. Computational tool for the characterisation of rapid fluctuations in flow and stage in rivers caused by hydropeaking. Environ. Modell. Softw. 2014, 55, 266-278. [CrossRef]

79. Bruder, A.; Tonolla, D.; Schweizer, S.P.; Vollenweider, S.; Langhans, S.D.; Wüest, A. A conceptual framework for hydropeaking mitigation. Sci. Total Environ. 2016, 568, 1204-1212. [CrossRef] [PubMed]

80. Hill, T.; Levicki, P. Statistics Methods and Applications; StatSoft: Madison, WI, USA, 2005; p. 800.

81. Čekanavičius, V.; Murauskas, G. Taikomoji Regresine Analize Socialiniuose Tyrimuose/Applied Regression Analysis in Social Research; Vilniaus Universiteto Leidykla: Vilnius, Lithuania, 2014. (In Lithuanian)

82. Sheskin, D.J. Handbook of Parametric and Nonparametric Statistical Procedures, 3rd ed.; Printed in the United States of America; Chapman \& Hall/CRC: New York, NY, USA, 2004; p. 1184.

83. Musy, A.; Higy, C. Hydrology: A Science of Nature; CRC Press: Boca Raton, FL, USA, 2011; p. 356.

84. Zhao, W.; Guo, W.; Zhao, L.; Li, Q.; Cao, X.; Tang, X. Influence of Different Types of Small Hydropower Stations on Macroinvertebrate Communities in the Changjiang River Basin, China. Water 2019, 11, 1892. [CrossRef]

85. Freedman, J.A.; Lorson, B.D.; Taylor, R.B.; Carline, R.F.; Stauffer, J.R. River of the dammed: Longitudinal changes in fish assemblages in response to dams. Hydrobiologia 2014, 727, 19-33. [CrossRef]

86. Mbaka, J.G.; Mwaniki, M. A global review of the downstream effects of small impoundments on stream habitat conditions and macroinvertebrates. Environ. Rev. 2015, 23, 257-262. [CrossRef]

87. Smokorowski, K.E.; Metcalfe, R.A.; Jones, N.E.; Marty, J.; Niu, S.; Pyrce, R.S. Flow management: Studying ramping rate restrictions. Hydro Rev. 2009, 28, 68-87.

88. Ashraf, F.B.; Haghighi, A.T.; Riml, J.; Alfredsen, K.; Koskela, J.J.; Klöve, B.; Marttila, H. Changes in short term river flow regulation and hydropeaking in Nordic rivers. Sci. Rep. 2018, 8, 17232. [CrossRef] [PubMed]

89. Anderson, D.; Moggridge, H.; Warren, P.; Shucksmith, J. The impacts of 'run-of-river' hydropower on the physical and ecological condition of rivers. Water Environ. J. 2015, 29, 268-276. [CrossRef]

90. Juarez, A.; Adeva-Bustos, A.; Alfredsen, K.; Dønnum, B.O. Performance of A two-dimensional hydraulic model for the evaluation of stranding areas and characterization of rapid fluctuations in hydropeaking rivers. Water 2019, 11, 201. [CrossRef]

91. Sachdev, H.S.; Akella, A.K.; Kumar, N. Analysis and evaluation of small hydropower plants: A bibliographical survey. Renew. Sustain. Energy Rev. 2015, 51, 1013-1022. [CrossRef]

92. Hauer, C.; Holzapfel, P.; Leitner, P.; Graf, W. Longitudinal assessment of hydropeaking impacts on various scales for an improved process understanding and the design of mitigation measures. Sci. Total Environ. 2017, 575, 1503-1514. [CrossRef]

93. Šilinis, L.; Punys, P.; Radzevičius, A.; Kasiulis, E.; Dumbrauskas, A.; Jurevičius, L. An assessment of hydropeaking metrics of a large-sized hydropower plant operating in a lowland river, Lithuania. Water 2020, 12, 1404. [CrossRef]

94. Charmasson, J.; Zinke, P. Mitigation Measures against Hydropeaking Effects. A Literature Review; Report No. TR A7192-Unrestricted; Stiftelsen for Industriell og Teknisk Forskning (SINTEF): Trondheim, Norway, 2011.

95. Harby, A.; Noack, M. Rapid flow fluctuations and impacts on fish and the aquatic ecosystem. In Ecohydraulics: An Integrated Approach; Maddock, I., Harby, A., Kemp, P., Wood, P., Eds.; Wiley Blackwell: Hoboken, NJ, USA, 2013; pp. 323-334. 